\title{
Theranostics
}

Review

$2011 ; 1: 58-82$

\section{Radiolabeled Cyclic RGD Peptides as Radiotracers for Imaging Tumors and Thrombosis by SPECT}

\author{
Yang Zhou, Sudipta Chakraborty and Shuang Liu ${ }^{凶}$ \\ School of Health Sciences, Purdue University, West Lafayette, IN 47907, USA
}

Corresponding author: Dr. Shuang Liu, School of Health Sciences, Purdue University, 550 Stadium Mall Drive, West Lafayette, IN 47907, USA; Tel: 765-494-0236; E-mail: liu100@purdue.edu

(c) Ivyspring International Publisher. This is an open-access article distributed under the terms of the Creative Commons License (http://creativecommons.org/ licenses/by-nc-nd/3.0/). Reproduction is permitted for personal, noncommercial use, provided that the article is in whole, unmodified, and properly cited.

Published: 2011.01 .18

\begin{abstract}
The integrin family is a group of transmembrane glycoprotein comprised of $19 \alpha$ - and $8 \beta$-subunits that are expressed in 25 different $\alpha / \beta$ heterodimeric combinations on the cell surface. Integrins play critical roles in many physiological processes, including cell attachment, proliferation, bone remodeling, and wound healing. Integrins also contribute to pathological events such as thrombosis, atherosclerosis, tumor invasion, angiogenesis and metastasis, infection by pathogenic microorganisms, and immune dysfunction. Among 25 members of the integrin family, the $\alpha_{v} \beta_{3}$ is studied most extensively for its role of tumor growth, progression and angiogenesis. In contrast, the $\alpha_{1 \mathrm{Il}} \beta_{3}$ is expressed exclusively on platelets, facilitates the intercellular bidirectional signaling ("inside-out" and "outside-in") and allows the aggregation of platelets during vascular injury. The $\alpha_{11 \mathrm{~b}} \beta_{3}$ plays an important role in thrombosis by its activation and binding to fibrinogen especially in arterial thrombosis due to the high blood flow rate. In the resting state, the $\alpha_{11 b} \beta_{3}$ on platelets does not bind to fibrinogen; on activation, the conformation of platelet is altered and the binding sites of $\alpha_{11 b} \beta_{3}$ are exposed for fibrinogen to crosslink platelets. Over the last two decades, integrins have been proposed as the molecular targets for diagnosis and therapy of cancer, thrombosis and other diseases. Several excellent review articles have appeared recently to cover a broad range of topics related to the integrin-targeted radiotracers and their nuclear medicine applications in tumor imaging by single photon emission computed tomography (SPECT) or a positron-emitting radionuclide for positron emission tomography (PET). This review will focus on recent developments of $\alpha_{v} \beta_{3}$-targeted radiotracers for imaging tumors and the use of $\alpha_{1 \mathrm{lb}} \beta_{3}$-targeted radiotracers for thrombosis imaging, and discuss different approaches to maximize the targeting capability of cyclic RGD peptides and improve the radiotracer excretion kinetics from non-cancerous organs. Improvement of target uptake and target-to-background ratios is critically important for target-specific radiotracers.
\end{abstract}

Key words: Integrin av $\beta 3$; Integrin aIIb $\beta 3$; cyclic RGD peptides; tumor; thrombosis; SPECT.

\section{INTRODUCTION}

Radiopharmaceuticals, which are also called radiotracers, are drugs containing a radionuclide. Radiotracers are used routinely in nuclear medicine for diagnosis or therapy of diseases, such as cancer, inflammation and myocardial infarction [1-6]. Radio- tracers can be classified according to the biodistribution characteristics: those whose biodistribution is determined exclusively by their chemical and physical properties; and those whose biological properties are determined by the receptor binding capability of 
radiolabeled biomolecules. The latter class is often called target-specific radiotracers [3, 4]. Diagnostic radiotracers are molecules labeled with either a $\gamma$-emitting isotope for single photon emission computed tomography (SPECT) or a positron-emitting radionuclide for positron emission tomography (PET), and provide a method of assessing the disease or disease states by SPECT or PET. They are also useful for monitoring the treatment efficacy of a specific therapeutic regimen in a noninvasive fashion.

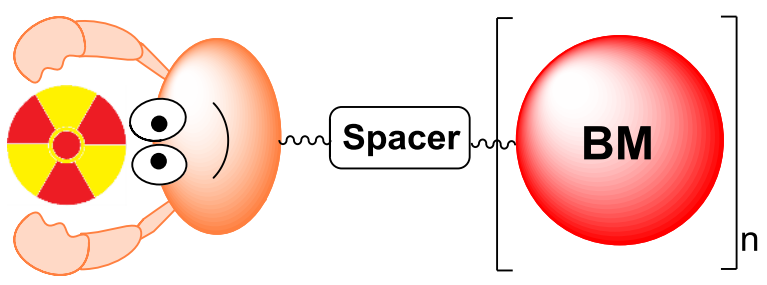

Figure I. Schematic presentation of the target-specific radiotracer. Radionuclide is the radiation source. BM is the targeting biomolecule for receptor binding. A multidentate bifunctional chelator is used for chelation of metallic radionuclides. A spacer is used to bridge the radiometal chelate and targeting biomolecule.

Fig. 1 shows the schematic illustration of the target-specific radiotracers, which are often radiometal complexes of a chelator-biomolecule conjugate. In some cases, they can be biomolecules attached with a non-metallic radionuclide, such as ${ }^{18} \mathrm{~F}$ and ${ }^{123} \mathrm{I}$. A target-specific radiotracer is based on the receptor binding of the radiolabeled receptor ligand in the diseased tissue [7-20]. The metal-containing target-specific radiotracer can be divided into four parts: targeting biomolecule (BM), spacer, bifunctional chelating agent $(\mathrm{BFC})$, and radionuclide. The targeting biomolecule serves as a "carrier" for target-specific delivery of radionuclide to the diseased tissue with many targeted receptors. The radiolabeled receptor ligand binds to these receptors with high affinity and specificity, resulting in selective uptake of the radiotracer. The choice of a radionuclide depends on the clinical utility of the radiotracer. Table $\mathbf{1}$ lists several selected radionuclides useful for planar imaging and SPECT, along with their nuclear characteristics. For SPECT, more than $80 \%$ of radiotracers used in nuclear medicine departments are ${ }^{99 \mathrm{~m}} \mathrm{Tc}$ compounds mainly due to the optimal nuclear properties of ${ }^{99} \mathrm{mTc}$ and its easy availability at low cost [1-5]. The $6 \mathrm{~h}$ half-life is long enough to allow radiopharmacists to carry out radiosynthesis and for physicians to collect clinically useful images. It is also short enough to permit administration of $20-30 \mathrm{mCi}$ of $99 \mathrm{mTc}$ radiotracer without imposing a significant radiation dose to the patient. ${ }^{111}$ In is also widely used in gamma scintigraphy (only second to ${ }^{99 \mathrm{~m} T c}$ in clinical applications). It decays by electron capture and emits two $\gamma$-photons of 173 and $247 \mathrm{keV}(90 \%$ and $94 \%$ abundance, respectively). ${ }^{111}$ In radiotracers are often used as the imaging surrogates for biodistribution and dosimetry determination of their corresponding therapeutic ${ }^{90} \mathrm{Y}$ analogs, which might be useful for treatment of cancer. ${ }^{67} \mathrm{Ga}$ is a cyclotron-produced radionuclide, and has a half-life of $78 \mathrm{~h} .{ }^{67} \mathrm{Ga}$ has little use in the development of target-specific radiotracers since ${ }^{68} \mathrm{Ga}$ radiotracers offer significant advantages because of the high spatial resolution of PET as compared to that of SPECT. Due to the low solution stability of $201 \mathrm{Tl}(\mathrm{I})$ complexes, ${ }^{201} \mathrm{Tl}$ is used exclusively as its chloride salt for myocardial perfusion imaging in the patients with cardiovascular diseases.

Table I. Selected radionuclides for SPECT.

\begin{tabular}{lllll}
\hline Radionuclide & Half-life & $\begin{array}{l}\text { Mode of } \\
\text { decay }\end{array}$ & $\begin{array}{l}\text { Principal } \gamma \text { emis- } \\
\text { sion in keV (\% } \\
\text { abundance) }\end{array}$ \\
\hline${ }^{99 \mathrm{mTc}}$ & $6.01 \mathrm{~h}$ & $\gamma$ & $140.5(87.2)$ \\
\hline${ }^{123 \mathrm{I}}$ & $13.27 \mathrm{~h}$ & $\mathrm{EC}$ & $159.0(83.3)$ \\
\hline${ }^{131} \mathrm{I}$ & $8.02 \mathrm{~d}$ & $\beta-\& \gamma$ & $364.5(81.2)$ \\
\hline${ }^{67} \mathrm{Ga}$ & $3.261 \mathrm{~d}$ & EC & $\begin{array}{l}93.3(37.0), 184.6 \\
(20.4)\end{array}$ \\
\hline${ }^{111} \mathrm{In}$ & $2.805 \mathrm{~d}$ & EC & $\begin{array}{l}171.3(90.2), 245.4 \\
(94.0)\end{array}$ \\
\hline${ }^{201} \mathrm{Tl}$ & $3.038 \mathrm{~d}$ & EC & $167.4(9.4)$ \\
\hline
\end{tabular}

Nuclear imaging techniques are widely used for clinical applications because of their high sensitivity. Nuclear imaging modalities (PET and SPECT) are able to determine concentrations of specific molecules in the human body in the picomolar range and provide enough sensitivity needed to visualize most interactions between physiological targets and receptor ligands. Many biomolecules (monoclonal antibodies, peptides, or non-peptide receptor ligands) have been successfully used for target-specific delivery of radionuclides. Among them, small peptides with less than 30 amino acids or molecular weight less than 3500 Daltons are of particular interest. Compared to monoclonal antibodies and antibody fragments, small peptides offer several advantages. Peptides are necessary elements in more fundamental biological processes than any other class of molecule. They can also 
tolerate harsher conditions for chemical modification or radiolabeling. Small peptides are easy to synthesize and modify, less likely to be immunogenic, and can have rapid blood clearance. The faster blood clearance results in adequate $\mathrm{T} / \mathrm{B}$ ratios earlier so that it is practical to use $99 \mathrm{mTc}$, which is the preferred radionuclide for diagnostic nuclear medicine. In most cases, the primary sites of interactions of peptides are receptors on the outer surface of cell membranes (extracellular). All these factors make small bioactive peptides excellent candidates for development of target-specific radiotracers. The peptide-based radiotracers have been reviewed extensively [7-20].

The integrin family is comprised of 25 identified members, which are heterodimers of 19 a- and 8 $\beta$-subunits imbedded non-covalently into the cell membrane [21]. The member of this family is still expanding as observed from human genome studies [22]. The cell-cell and cell-matrix adhesion processes through binding of integrins to their ligands play critical roles in physiological processes, including cell attachment, proliferation [23-25], bone remodeling [26], and wound healing [27]. Besides, integrins also contribute to pathological events such as thrombosis, atherosclerosis [28, 29], tumor invasion, angiogenesis and metastasis [30-33], infection by pathogenic microorganisms [34, 35], and immune dysfunction [36]. Therefore, the integrins have been proposed as the molecular targets for the treatment of cancer [37-42], thrombosis [43, 44] and other diseases [45, 46] in the last two decades. The role of integrins has been reviewed extensively [21, 47-50].

Many integrin family members are crucial to the initiation, progression and metastasis of solid tumors. Epithelial-derived tumor cells generally retain integrins expressed by epithelial cells including $\alpha_{6} \beta_{4}, \alpha_{6} \beta_{1}$, $\alpha_{v} \beta_{5}, \alpha_{2} \beta_{1}$ and $\alpha_{3} \beta_{1}$, and mediate the adhesion, migration, proliferation and survival of tumor cells. Different integrins can promote or suppress the tumor development. For example, integrin $\alpha_{2} \beta_{1}$ is down-regulated in tumor cells, the phenomenon associated with increased tumor cell dissemination [51]. This suggests that $\alpha_{2} \beta_{1}$ could function as a tumor suppressor [52]. On the other hand, the expression of $a_{v} \beta_{3}, a_{v} \beta_{5}, a_{5} \beta_{1}, a_{6} \beta_{4}, a_{4} \beta_{1}$ and $a_{v} \beta_{6}$ on tumor cells is correlated with disease progression in various tumor types [53-58]. More importantly, the expression of integrins $\alpha_{v} \beta_{3}, \alpha_{5} \beta_{1}$ and $\alpha_{v} \beta_{6}$ are usually at low or undetectable levels in most adult epithelia. Among 25 members of the integrin family, integrin $a_{v} \beta_{3}$ is studied most extensively for its role in the tumor growth and angiogenesis. While the $\alpha_{v} \beta_{3}$ plays pivotal role in the tumor growth and progression, the $\alpha_{\text {IIB }} \beta_{3}$ is critical for platelet aggregation during thrombosis. It is be- lieved that the interaction between the tumor $\alpha_{v} \beta_{3}$ and platelet $\alpha_{I I b} \beta_{3}$ is also related to the increased tumor metastasis via a bridge such as fibrinogen, von Willebrand factor or thrombospondin [59]. This interaction is believed to facilitate the tumor cell adhesion to the vasculature, and often leads to metastasis to various secondary sites, including bone marrow [60].

Integrin $\alpha_{\text {IIB }} \beta_{3}$ is exclusively expressed on platelets, although $\alpha_{v} \beta_{3}, a_{2} \beta_{1}, a_{5} \beta_{1}$ and $\alpha_{6} \beta_{1}$ can also mediate platelet adhesion functions [61]. On the surface of platelet, there are 70 90 thousand copies of $\alpha_{\text {IIB }} \beta_{3}$, which facilitate the intercellular bidirectional signaling ("inside-out" and "outside-in") and allow the aggregation of platelets during the vascular injury. The $\mathrm{a}_{\mathrm{IIB}} \beta_{3}$ plays an important role in thrombosis formation by its activation and binding to fibrinogen especially in arterial thrombi due to the high blood flow rate. In the resting state, the $\alpha_{\text {IIB }} \beta_{3}$ on platelets does not bind to fibrinogen. On activation, the conformation of platelet is altered and the binding sites of $\mathrm{a}_{\mathrm{IIB}} \beta_{3}$ are exposed for fibrinogen to crosslink with the activated platelets. Integrin $\alpha_{I I B} \beta_{3}$ antagonists have been widely used in the antithrombotic therapy in the patients with percutaneous coronary interventions and unstable angina $[47,48,62-65]$.

The $\alpha_{v} \beta_{3}$ and $\alpha_{\text {IIB }} \beta_{3}$ receptor ligands share a common RGD tripeptide binding sequence. Generally, linear RGD peptides, such as GRGDS (Gly-Arg-Gly-Asp-Ser), often have low affinity ( $\mathrm{IC}_{50}>$ $100 \mathrm{nM}$ ) and selectivity for $\alpha_{\mathrm{v}} \beta_{3}$ and $\alpha_{\mathrm{IIB}} \beta_{3}$ [66], and undergo rapid degradation in serum by a variety of proteases $[67,68]$. It has been shown that cyclization of RGD peptides via linkers, such as S-S disulfide, thioether and rigid aromatic rings, often leads to the increased receptor binding affinity and selectivity [67-77]. It has been reported that the $\alpha_{I I B} \beta_{3}$ is less sensitive to variations in the RGD backbone structure and can accommodate a larger distance or spacer than $\alpha_{v} \beta_{3}$ and $\alpha_{v} \beta_{5}$ [66]. On the basis of extensive structure-activity-relationship studies, it was found that incorporation of the RGD unit into a cyclic the pentapeptide framework (Fig. 2: top) increases binding affinity and selectivity for $\alpha_{\mathrm{v}} \beta_{3}$ over $\alpha_{\mathrm{IIB}} \beta_{3}[66,68-77]$, while addition of a rigid aromatic ring (Fig. 2: DMP728 and DMP757) into the cyclic hexapeptide structure enhance the receptor binding affinity and selectivity for $\alpha_{I I B} \beta_{3}$ over both $\alpha_{\mathrm{v}} \beta_{3}$ and $\alpha_{\mathrm{v}} \beta_{5}[66,79$, 80]. It was also found that the valine residue in $c($ RGDfV) could be readily replaced by lysine (K) or glutamic acid (E) to afford c(RGDfK) or c(RGDfE), without significantly changing the $\alpha_{v} \beta_{3}$ binding affinity [69-71]. Similar behavior was also seen for $\mathrm{a}_{\text {IIB }} \beta_{3}$-selective hexapeptides [66]. 


\section{$\alpha_{v} \beta_{3}$-Targeted Cyclic Pentapeptides}

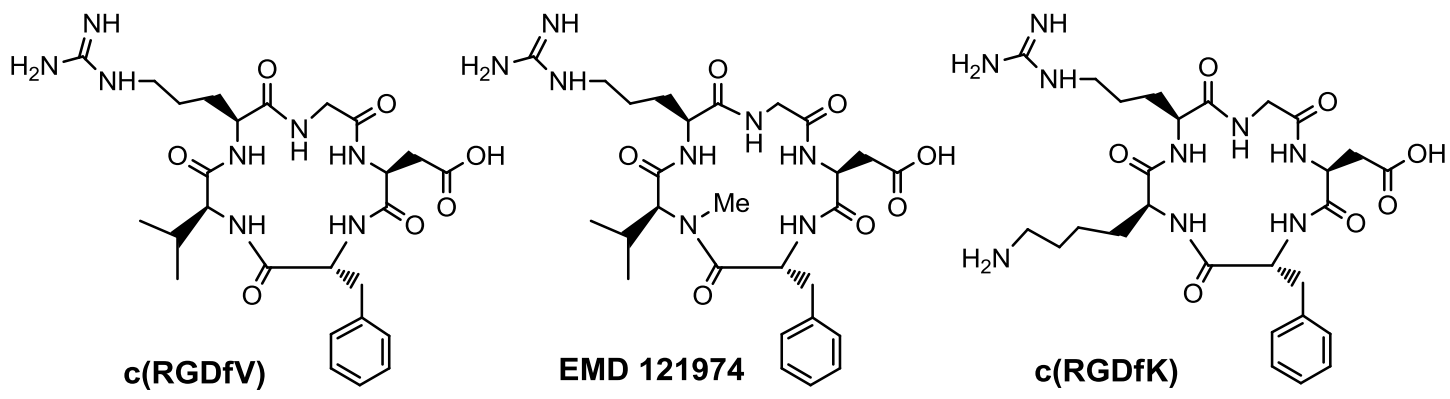

$\alpha_{l 1 \mathrm{~b}} \beta_{3}$-Targeted Cyclic Hexapeptides
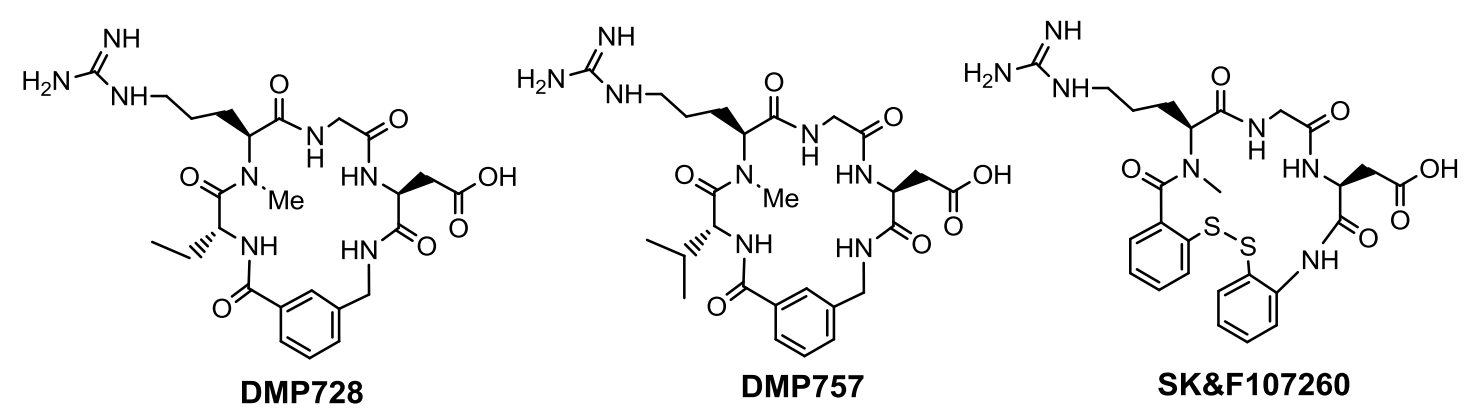

Figure 2. Examples of monomeric cyclic RGD peptides. Incorporation of the RGD sequence into a cyclic pentapeptide framework increases the binding affinity and selectivity for $\alpha_{v} \beta_{3}$ over $\alpha_{v} \beta_{5}$ and $\alpha_{118} \beta_{3}$, while the addition of one or two rigid aromatic rings into cyclic hexapeptide structure enhance the binding affinity and selectivity for the $\alpha_{118} \beta_{3}$ over $\alpha_{v} \beta_{3}$ and $\alpha_{v} \beta_{5}$.

Several excellent review articles have appeared recently to cover a broad range of topics related to integrin-targeted radiotracers and their nuclear medicine applications in tumor imaging by SPECT and PET [81-97]. This review is not intended to be an exhaustive review on all radiolabeled cyclic RGD peptides. Instead, it will focus on recent development of $\alpha_{v} \beta_{3}$-targeted SPECT radiotracers for imaging tumor angiogenesis and the use of the $\alpha_{\mathrm{IIb}} \beta_{3}$-targeted radiotracers for thrombosis imaging by SPECT. Because of the limited space, authors would apologize to those whose work has not been presented in detail, and for the omission of ${ }^{123}$ I-labeled cyclic RGD peptides as radiotracers in this review.

\section{2. $\alpha_{v} \beta_{3}$-TARGETED RADIOTRACERS FOR TUMOR IMAGING}

Integrin $\alpha_{v} \beta_{3}$ and tumor angiogenesis. Tumor cells produce many angiogenic factors, which are able to activate endothelial cells on the established blood vessels and induce endothelial proliferation, migra- tion, and new vessel formation (angiogenesis) through a series of sequential but partially overlapping steps [98-103]. Angiogenesis is a key requirement for both the tumor growth and metastasis. Without the formation of the new blood vessels which provide oxygen and nutrients, tumors cannot grow beyond 1 $2 \mathrm{~mm}$ in size [98, 103]. Angiogenesis is regulated by many proteins, such as vascular endothelial growth factor (VEGF), vascular endothelial growth factor receptors (VEGFR), G-protein coupled receptors for angiogenesis modulating proteins, endogenous angiogenesis inhibitors and integrins [102-105]. Among the angiogenesis factors, integrins are responsible for the cellular adhesion to extracellular matrix proteins in the intercellular spaces and basement membranes and subsequent migration of cells, and regulate cellular entry and withdraw from cell cycle [100, 107-110]. Among the integrins identified so far, the $\alpha_{v} \beta_{3}$ is studied most extensively since serves as a receptor for a variety of extracellular matrix proteins with the exposed RGD tripeptide sequence. These 
include vitronectin, fibronectin, fibrinogen, laminin, collagen, von Willebrand factor, and osteopontin [111-119]. The $\alpha_{v} \beta_{3}$ is usually expressed in relatively low levels on epithelial cells and mature endothelial cells, but is highly expressed in the tumors including osteosarcomas, neuroblastomas, glioblastomas, melanomas, breast, lung and prostate carcinomas [112-120]. Recently, it has been reported that the $\alpha_{v} \beta_{3}$ is overexpressed on not only tumor cells but also endothelial cells of the tumor neovasculature [121]. The $\alpha_{v} \beta_{3}$ expressed on the activated endothelial cells can modulate cell adhesion and migration during tumor angiogenesis, and its expression on carcinoma cells potentiates metastasis by facilitating invasion and movement of tumor cells across blood vessels [121]. It has also been demonstrated that the $\alpha_{v} \beta_{3}$ expression level correlates well with the potential for metastasis and the aggressiveness of many tumors including glioblastomas, melanoma, ovarian, breast and lung cancers $[113,119-121]$. Therefore, the $\alpha_{v} \beta_{3}$ has been identified as an interesting molecular target for the early diagnosis of rapidly growing and metastatic tumors [81-97].

Integrin $\alpha_{v} \beta_{3}$-targeted radiotracers under clinical investigation. Many radiolabeled cyclic RGD peptides have been evaluated as the $\alpha_{v} \beta_{3}$-targeted radiotracers [122-158]. Significant progress has been made on their use in tumor imaging by either SPECT or PET. Among the radiotracers evaluated in many preclinical tumor-bearing animal models, $\left[{ }^{18} \mathrm{~F}\right]$ Galacto-RGD (Fig. 3: top) and [ $\left.{ }^{18} \mathrm{~F}\right] \mathrm{AH} 111585$ (Fig. 3: middle) are currently under clinical investigation for non-invasive imaging of the $\alpha_{v} \beta_{3}$ expression in cancer patients [159-164]. Imaging studies clearly showed that the accumulation of ${ }^{18}$ F-labeled RGD peptide radiotracers correlated well with the tumor $\alpha_{\mathrm{v}} \beta_{3}$ expression levels in cancer patients [159-164]. However, their relatively low tumor uptake, high cost and lack of preparative modules for routine radiosynthesis will limit their continued clinical utilities. In addition, several steps of manual radiosynthesis and post-labeling purification can cause significant radiation exposure to radio-

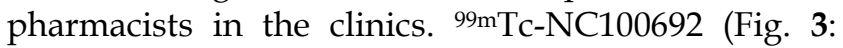
bottom) is a $99 \mathrm{~m}$ Tc-labeled cyclic RGD peptide monomer reportedly to have high integrin $\alpha_{v} \beta_{3}$ binding affinity [165]. In breast cancer patients, 19 of 22 malignant lesions (86\%) were detected by SPECT [165]. However, its intensive liver uptake and hepatobiliary excretion due to its lipophilic Tc-chelate (Fig. 3) will limit its continued clinical applications. Thus, there is a continuing need for more efficient $\alpha_{v} \beta_{3}$-specific $99 \mathrm{mTc}$ radiotracers that can be readily prepared from a kit formulation at low cost.
Multimer concept. Since interactions between the $\alpha_{v} \beta_{3}$ and RGD-containing proteins (e.g. vitronectin, fibronectin and fibrinogen) may involve multiple binding sites, the idea to use multimeric cyclic RGD peptides might provide more effective $\alpha_{v} \beta_{3}$ antagonists with tumor targeting capability and hence higher cellular uptake for their corresponding radiotracers [166]. Multivalent interactions are used in such a way that weak ligand-receptor interactions may become biologically relevant. The multimer concept has been used for enhancing the radiotracer tumor-targeting capability. For example, biodistribution studies

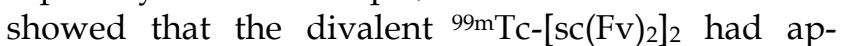
proximately 3-fold higher tumor uptake than

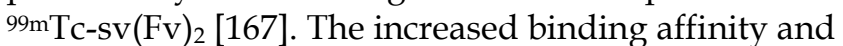
tumor targeting capability were also reported for the 125I-labeled divalent recombinant antibody fragment [168].

Multimeric cyclic RGD peptides. To improve $\alpha_{\mathrm{v}} \beta_{3}$ binding affinity, dimeric RGD peptides, such as $\mathrm{E}[\mathrm{c}(\mathrm{RGDfK})]_{2}$ (Fig. 4: $\mathrm{RGD}_{2}$ ), have been used to develop the $\alpha_{\mathrm{v}} \beta_{3}$-targeted radiotracers. Rajopadhye et al were the first to use $\mathrm{E}[\mathrm{c}(\mathrm{RGDfK})]_{2}$ to develop diagnostic $\left({ }^{99 \mathrm{mTc}}\right.$ and $\left.{ }^{64} \mathrm{Cu}\right)$ and therapeutic $\left({ }^{90} \mathrm{Y}\right.$ and $\left.{ }^{177} \mathrm{Lu}\right)$ radiotracers [146-157, 169, 170]. Dijkgraff et al found that the tumor uptake of ${ }^{111}$ In-labeled $E[c(R G D f K)]_{2}$ was $>2 x$ of that for its corresponding monomeric analog in athymic mice with xenografted SK-RC-52 tumors [154]. The same group also reported the DOTA-conjugated cyclic RGD dimers and tetramers $[154,155]$, but no in vivo data was presented. Recently, Chen and coworkers reported ${ }^{64} \mathrm{Cu}$ and ${ }^{18} \mathrm{~F}$-labeled $\mathrm{E}[\mathrm{c}(\mathrm{RGDyK})]_{2}$ as PET radiotracers $[140,141]$. Poethko et al also found that the RGDfE dimer [c(RGDfE)-HEG] ${ }_{2}-\mathrm{K}$ (Fig. 4) had much better targeting capability than the monomer c(RGDfE)-HEG [128-130]. The multimer concept was also used to prepare cyclic RGD tetramers [142, 144, 153, 155, 171-173] and octamers [173]. For example, Boturyn et al reported a series of cyclic RGDfK tetramers [172], and found that increasing the peptide multiplicity significantly enhanced the $\alpha_{\mathrm{v}} \beta_{3}$ binding affinity and internalization. Kessler et al reported a cyclic RGDfE tetramer (Fig. 5) that had better $\alpha_{v} \beta_{3}$ binding affinity than its corresponding dimer counterpart [128-130]. Liu et al used E[E[c(RGDfK) $\left.]_{2}\right]_{2}$ (Fig. 5: $\mathrm{RGD}_{4}$ ) for the development of $\alpha_{\mathrm{v}} \beta_{3}$-targeted diagnostic (99mTc and ${ }^{64} \mathrm{Cu}$ ) radiotracers $[142,153]$. Chen et al also reported the use of ${ }^{64} \mathrm{Cu}$ and ${ }^{18} \mathrm{~F}$-labeled cyclic RGD peptide tetramer $\mathrm{E}\left[\mathrm{E}[\mathrm{c}(\mathrm{RGDyK})]_{2}\right]_{2}$ and octamer $\mathrm{E}\left[\mathrm{E}\left[\mathrm{E}[\mathrm{c}(\mathrm{RGDyK})]_{2}\right]_{2}\right]_{2}$ for tumor imaging by PET [173]. Both the in vitro assays and the ex vivo biodistribution studies showed that the radiolabeled multimeric cyclic RGD peptides had better tumor uptake with 
longer tumor retention time than their dimeric analogs. However, their T/B ratios were not substantially better due to their high uptake in the normal organs [173]. It remains unclear if the multimeric cyclic RGD peptides, such as $\mathrm{E}\left[\mathrm{E}\left[\mathrm{E}[\mathrm{c}(\mathrm{RGDyK})]_{2}\right]_{2}\right]_{2}$, are really multivalent. Moreover, the cost for synthesis of the RGD octamer $\mathrm{E}\left[\mathrm{E}\left[\mathrm{E}[\mathrm{c}(\mathrm{RGDyK})]_{2}\right]_{2}\right]_{2}$ is prohibitively high for future development of the $\alpha_{\mathrm{v}} \beta_{3}$-targeted diagnostic radiotracers. Thus, an alternate approach is needed to improve the $\alpha_{v} \beta_{3}$-targeting capability of the radiotracer and minimize its accumulation in normal organs.

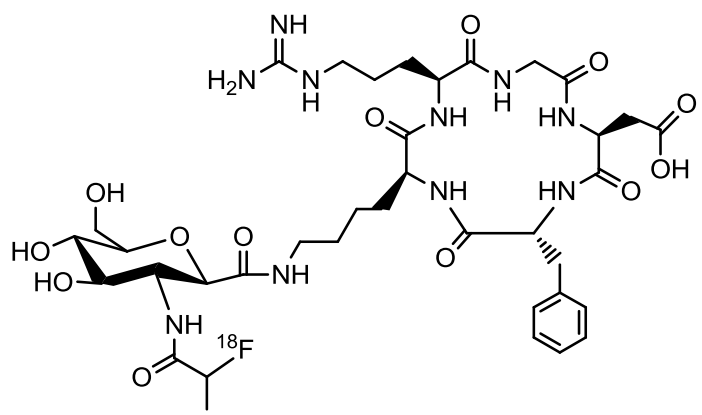

$\left[{ }^{18} \mathrm{~F}\right]$ Galacto-RGD

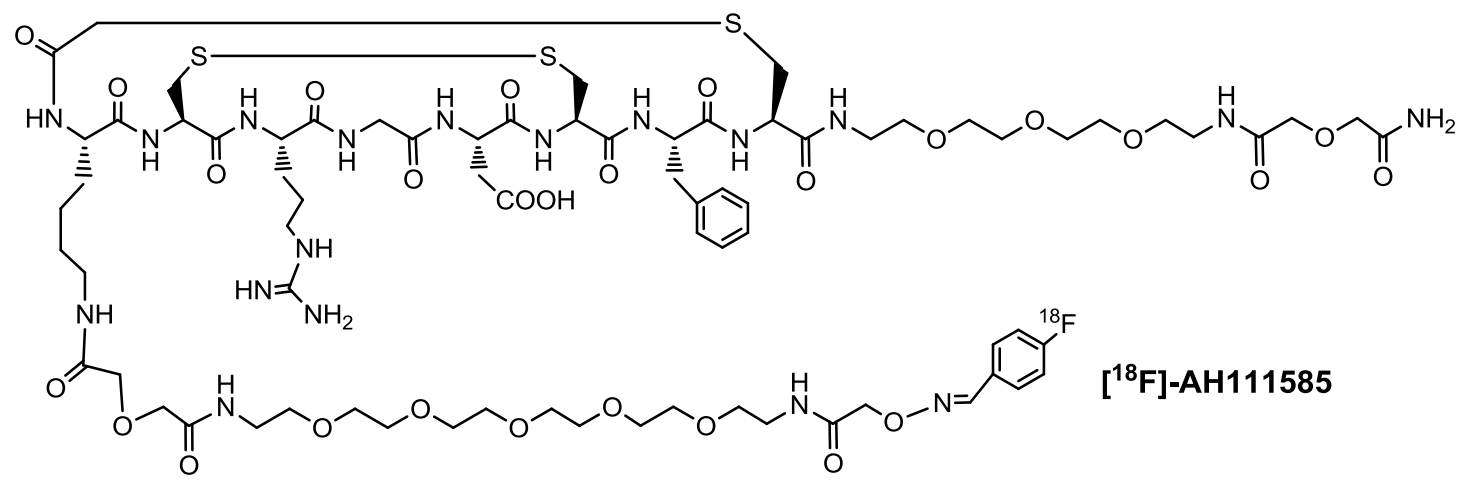

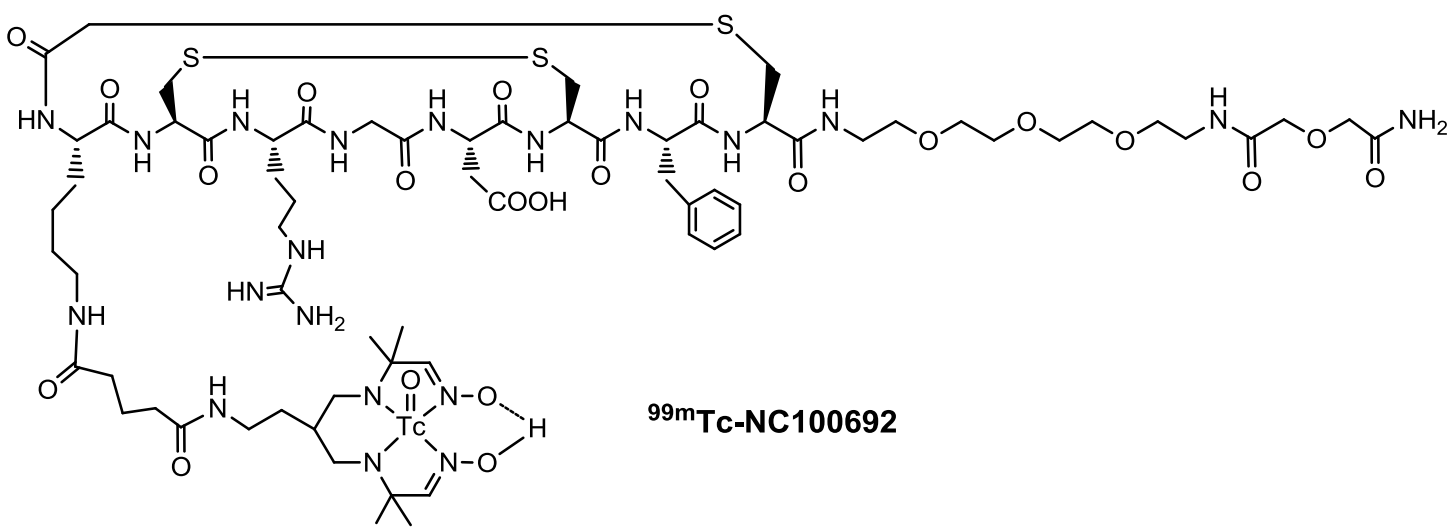

Figure 3. Examples of radiolabeled cyclic RGD peptide monomers as radiotracers $\left(\left[{ }^{18} \mathrm{~F}\right] \mathrm{Galacto}-\mathrm{RGD},\left[{ }^{18} \mathrm{~F}\right] \mathrm{AHI}\right.$ I I 585 and ${ }^{99 \mathrm{~m}} \mathrm{Tc}-\mathrm{NCl}$ 00692) for imaging tumor angiogenesis. They are currently under clinical investigation for noninvasive visualization of the $\alpha_{v} \beta_{3}$ expression in cancer patients. 


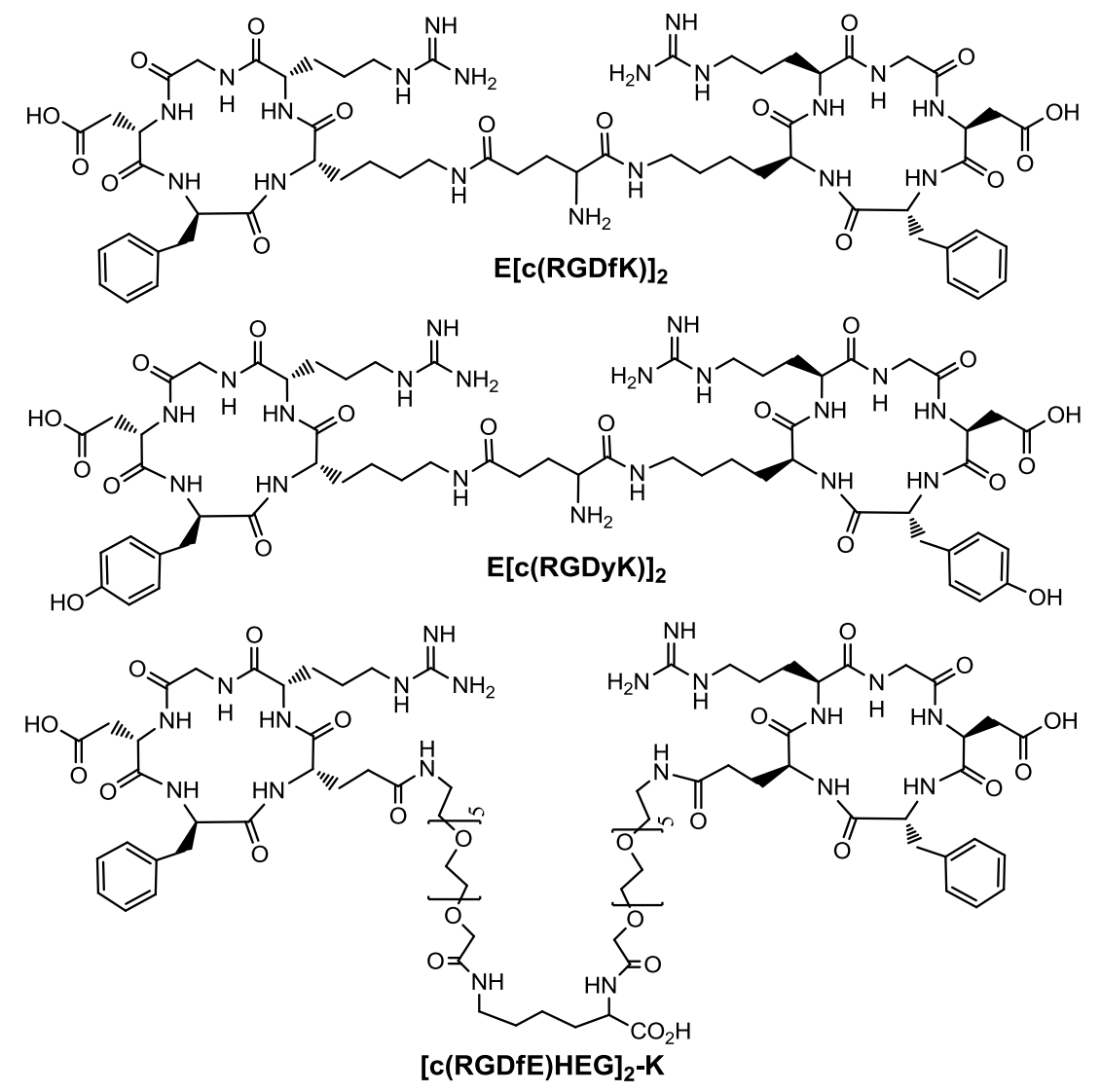

Figure 4. Examples of RGD dimers $\left(E[c(R G D f K)]_{2}, E[c(R G D y K)]_{2}\right.$ and $\left.[c(R G D f E) H E G]_{2}-K\right)$ for $\alpha_{v} \beta_{3}$-targeting.

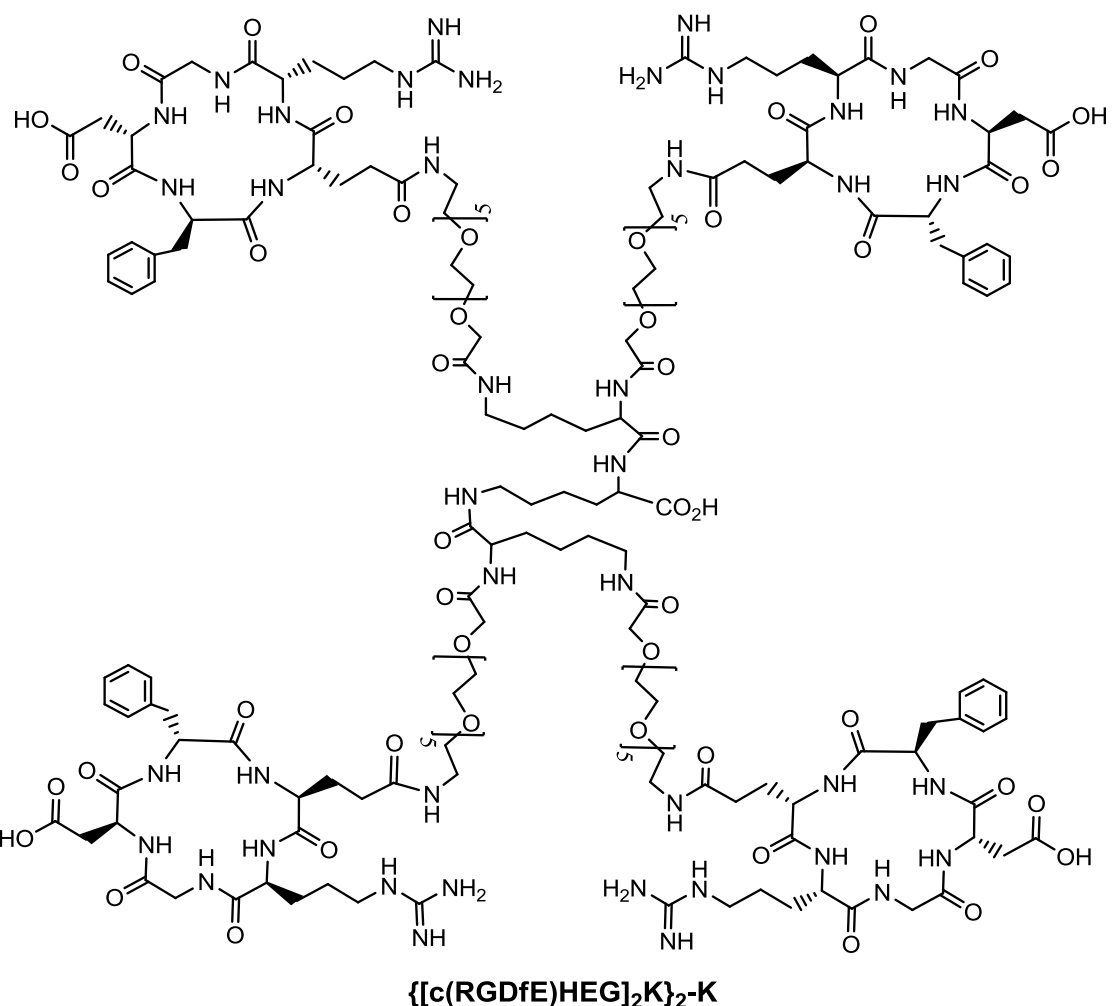

Fiure 5. Structure of a cyclic RGD tetramer $\left[[c(R G D f E) H E G]_{2} K\right]_{2}-K$. 


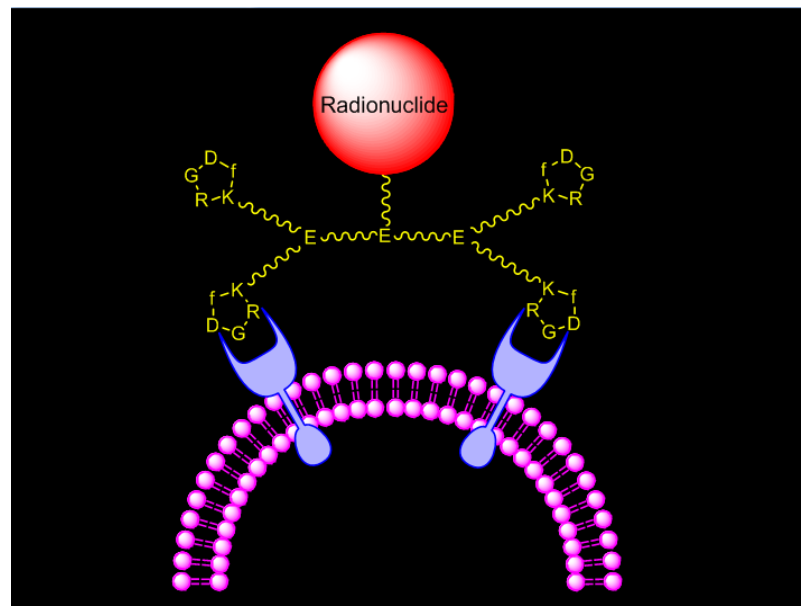

Figure 6. Schematic illustration of interactions between a cyclic RGD tetramer and the integrin $\alpha_{v} \beta_{3}$ receptor.

Improve $a_{v} \beta_{3}$ binding affinity via bivalency. Fig. $\mathbf{6}$ illustrates the interaction between $\alpha_{\mathrm{v}} \beta_{3}$ and a cyclic RGD tetramer. The targeting moiety is $\mathrm{c}(\mathrm{RGDfK})$. The spacer is glutamic acid (E) or its derivatives. Two factors contribute to the high $\alpha_{\mathrm{v}} \beta_{3}$ binding affinity of multimeric cyclic RGD peptides: bivalency and the enhanced local RGD concentration. The key for bivalency is the distance between two adjacent cyclic RGD motifs. If this distance is long enough for simultaneous $\alpha_{v} \beta_{3}$ binding, the cyclic RGD multimer will bind to $\alpha_{v} \beta_{3}$ in a bivalent fashion. If this distance is too short, the local cyclic RGD peptide concentration is still "enriched" in the vicinity of neighboring $\alpha_{\mathrm{v}} \beta_{3}$ sites once the first RGD motif is bound. The combination of simultaneous $\alpha_{v} \beta_{3}$ binding (bivalency factor) and the locally enriched RGD concentration (concentration factor) will result in higher $\alpha_{\mathrm{v}} \beta_{3}$ binding affinity for cyclic RGD multimers and better tumor uptake with longer tumor retention for their corresponding radiotracers.

To demonstrate the proof-of-principle for the bivalency concept, Shi et al recently reported a series of cyclic RGD dimers (Fig. 7) with $\mathrm{G}_{3}$ (Gly-Gly-Gly) and $\mathrm{PEG}_{4}$ (15-amino-4,7,10,13-tetraoxapentadecanoic acid) linkers [174-181]. The $\mathrm{G}_{3}$ and $\mathrm{PEG}_{4}$ linkers were used to increase the distance between two RGD motifs from 6 bonds in $\mathrm{RGD}_{2}$ to 24 bonds in 3G-RGD 2 and 38 bonds in $3 P-R^{2} D_{2}[174,175]$. The $a_{v} \beta_{3}$ binding affinities (Table 2) against ${ }^{125}$ I-echistatin bound to U87MG human glioma cells follow the order of HYNIC-RGD 4 $\left(\mathrm{IC}_{50}=7 \pm 2 \mathrm{nM}\right)>$ HYNIC-2P-RGD $\left(\mathrm{IC}_{50}=52 \pm 7 \mathrm{nM}\right)$ $\sim$ HYNIC-3P-RGD $2\left(\mathrm{IC}_{50}=60 \pm 4 \mathrm{nM}\right) \sim$ HYNIC-3G$\mathrm{RGD}_{2}\left(\mathrm{IC}_{50}=61 \pm 2 \mathrm{nM}\right)>$ HYNIC-P-RGD $\left(\mathrm{IC}_{50}=84 \pm\right.$ $7 \mathrm{nM}) \sim$ HYNIC-RGD $\left(\mathrm{IC}_{50}=112 \pm 21 \mathrm{nM}\right)>>$ HYNIC-G-RGD $\left(\mathrm{IC}_{50}=358 \pm 8 \mathrm{nM}\right)>$ HYNIC-P-RGD $\left(\mathrm{IC}_{50}=452 \pm 11 \mathrm{nM}\right)$. A similar trend was observed for their DOTA-conjugates against ${ }^{125} \mathrm{I}-\mathrm{c}(\mathrm{RGDyK})$ bound to U87MG glioma cells [176]: DOTA-RGD $4\left(\mathrm{IC}_{50}=1.3\right.$ $\pm 0.3 \mathrm{nM}) \sim$ DOTA-3P-RGD $2\left(\mathrm{IC}_{50}=1.3 \pm 0.3 \mathrm{nM}\right) \sim$ DOTA-3G-RGD $2\left(\mathrm{IC}_{50}=1.1 \pm 0.2 \mathrm{nM}\right)>$ DOTA-RGD 2 $\left(\mathrm{IC}_{50}=8.0 \pm 2.8 \mathrm{nM}\right)>>$ DOTA-P-RGD $\left(\mathrm{IC}_{50}=42.1 \pm\right.$ $3.5 \mathrm{nM}) \sim \mathrm{c}($ RGDfK $)\left(\mathrm{IC}_{50}=38.5 \pm 4.5 \mathrm{nM}\right)>>$ DOTA-3P-RGK $2\left(\mathrm{IC}_{50}=452 \pm 11 \mathrm{nM}\right)$. These data suggest that the $\mathrm{G}_{3}$ and $\mathrm{PEG}_{4}$ linkers between two RGD motifs are responsible for the improved $a_{v} \beta_{3}$ binding affinity of HYNIC-3P-RGD ${ }_{2}$ and HYNIC-3G-RGD 2 as compared to HYNIC-P-RGD 2 $[174,175]$. The higher $\alpha_{v} \beta_{3}$ binding affinity of HYNIC-RGD ${ }_{4}$ is likely due to the presence of its two extra RGD motifs in $\mathrm{RGD}_{4}$ as compared to those in HYNIC-3P-RGD ${ }_{2}$ and HYNIC-3G-RGD 2 [174].

It is important to note that the $\mathrm{IC}_{50}$ values of cyclic RGD peptides are largely dependent on the type of assay (the immobilized $\alpha_{v} \beta_{3}$-binding assay vs whole-cell $\alpha_{\mathrm{v}} \beta_{3}$ competition assay), the radioligand (125I-c(RGDyK) vs ${ }^{125}$ I-echistatin) and tumor cell lines (U87MG vs MDA-MB-435). Caution should be taken when comparing their $\mathrm{IC}_{50}$ values. Whenever possible, a "control compound", such as c(RGDfK) and $c($ RGDyK), should be used in each experiment. In addition, the $\mathrm{IC}_{50}$ values obtained from the in vitro assays cannot be used as the "absolute proof" to support the concept of bivalency. They must be used in combination with the biodistribution data of their corresponding radiotracers.

To prove the bivalency of cyclic RGD dimers (Fig. 7: $3 \mathrm{P}-\mathrm{RGD}_{2}$ and $3 \mathrm{G}-\mathrm{RGD}_{2}$ ), complexes 99mTc-3P-RGD 2 and $99 \mathrm{mTc}-3 \mathrm{G}-\mathrm{RGD}_{2}$ (Fig. 8) were evaluated in the athymic nude mice bearing U87MG human glioma and MDA-MB-435 human breast tumor xenografts $[174,175]$. For comparison purposes, ${ }^{99} \mathrm{mTc}-\mathrm{P}-\mathrm{RGD}_{2}$ and ${ }^{99} \mathrm{mTc}^{-R G D} 4$ (Fig. 8) were also evaluated using the same tumor-bearing animal models [174, 175]. As expected, the breast tumor uptake of ${ }^{99 m T c-3 P-R G D}$ and ${ }^{99 m}$ Tc-3G-RGD 2 was comparable to that of $99 \mathrm{mTc}-R_{\mathrm{TD}}$ (Fig. 8), and was $>2 \mathrm{x}$ higher than that of $99 \mathrm{~m}$ Tc-P-RGD 2 [174]. These data strongly suggest that $\mathrm{RGD}_{4}, 3 \mathrm{P}-\mathrm{RGD}_{2}$ and $3 \mathrm{G}-\mathrm{RGD}_{2}$ are bivalent and $\mathrm{P}-\mathrm{RGD}_{2}$ is only monodentate in binding to the integrin $\alpha_{v} \beta_{3}$ even though it has two RGD motifs. Similar conclusion was also made for 3P-RGD ${ }_{2}$ in ${ }^{64} \mathrm{Cu}($ DOTA-3P-RGD $)$ [176], 3G-RGD ${ }_{2}$ in ${ }^{64} \mathrm{Cu}\left(\mathrm{DOTA}-3 \mathrm{G}-\mathrm{RGD}_{2}\right)$ [176], $\mathrm{G}_{3}-2 \mathrm{P}_{4}-\mathrm{RGD}_{2}$ in ${ }^{99} \mathrm{mTc}-\mathrm{G}_{3}-2 \mathrm{P}_{4}-\mathrm{RGD}_{2}$ [177], and $2 \mathrm{P}-\mathrm{RGD}_{2}$ in their ${ }^{68} \mathrm{Ga}$ and ${ }^{18} \mathrm{~F}$ radiotracers $[178,179]$. If $\mathrm{P}-\mathrm{RGD}_{2}$ were bivalent, HYNIC-P-RGD 2 would have had the same $\alpha_{v} \beta_{3}$ binding affinity as HYNIC-3P-RGD ${ }_{2}$ and HYNIC-3G-RGD 2 while ${ }^{99}$ Tc-P-RGD 2 would have shared the same tumor uptake with ${ }^{99 \mathrm{~m} T \mathrm{c}-3 \mathrm{P}-\mathrm{RGD}_{2}}$ and ${ }^{99 m T c}-3 \mathrm{G}-\mathrm{RGD}_{2}$. 


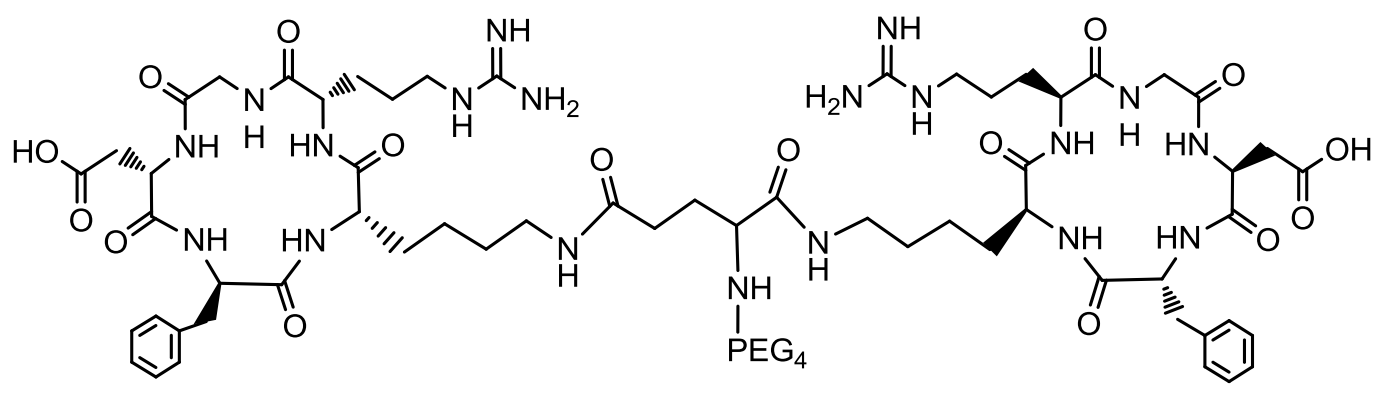<smiles>[R6]OC(=O)O[R6](=O)[O-]</smiles>

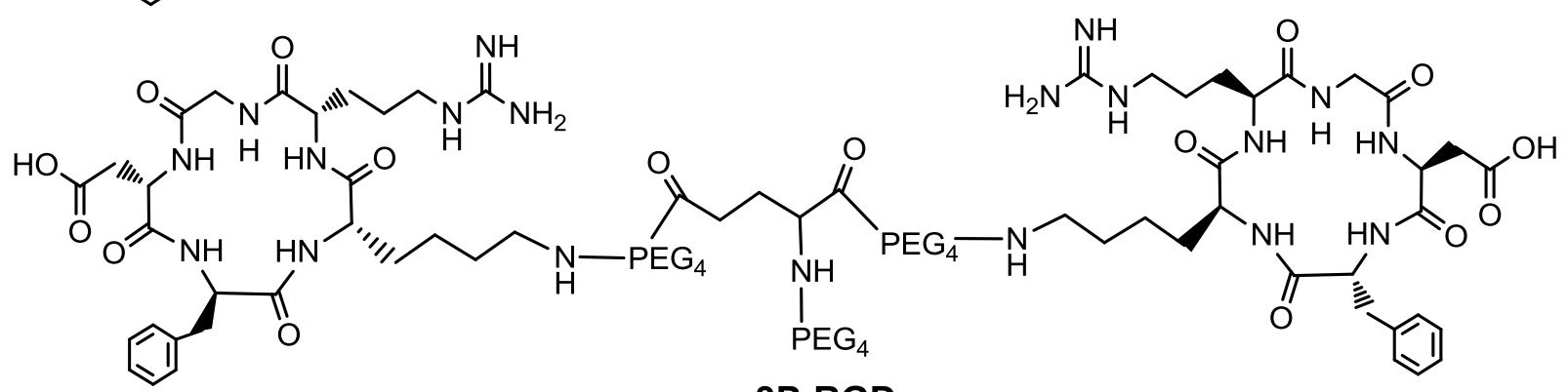<smiles>[R6][R6]#[R6][R6]</smiles>

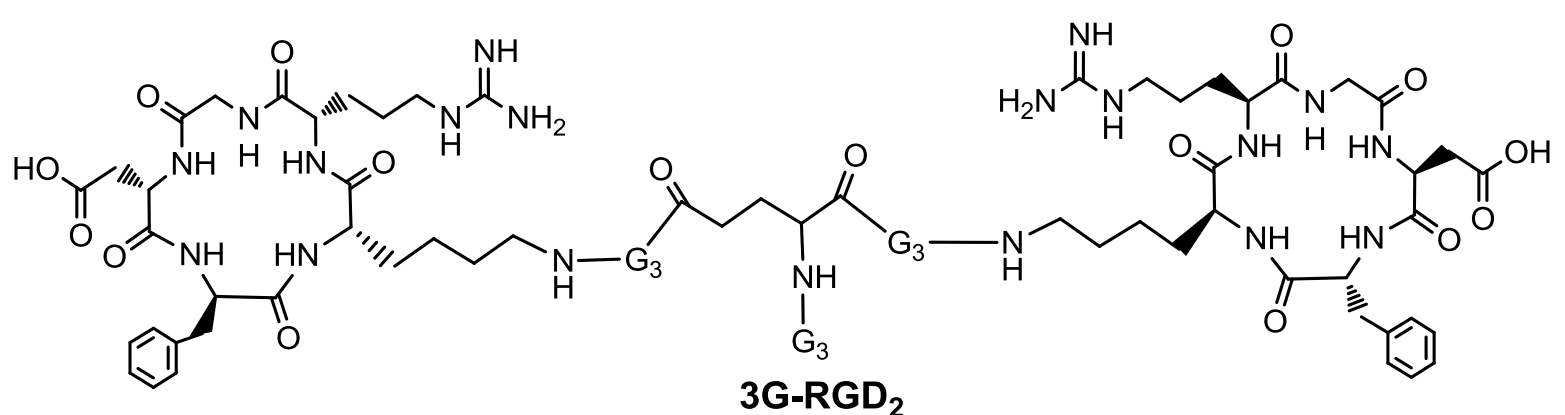

$$
\mathrm{PEG}_{4}=\mathrm{H}_{2} \mathrm{~N}
$$

Figure 7. Examples of cyclic RGD dimers with $\mathrm{PEG}_{4}$ and $\mathrm{G}_{3}$ linkers, which are used to increase the distance between two RGD motifs and to improve radiotracer excretion kinetics from normal organs. 

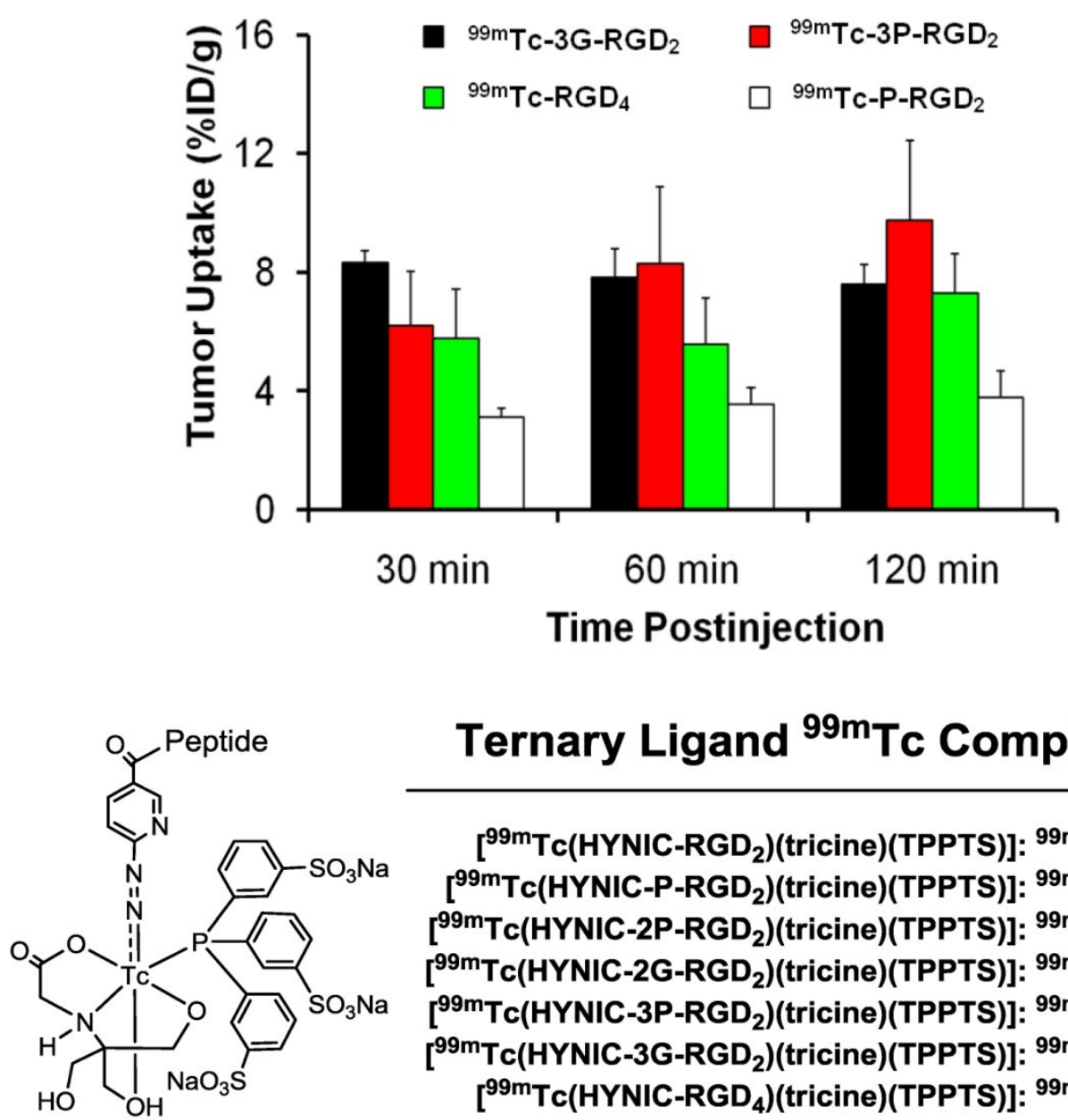

Ternary Ligand ${ }^{99 m}$ Tc Complexes

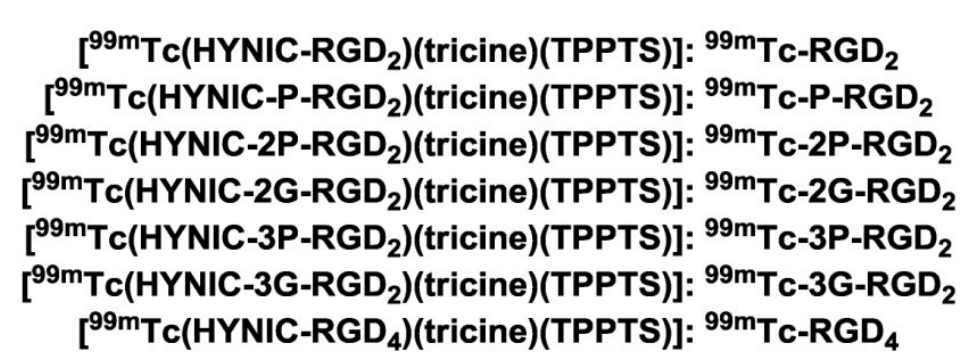

Figure 8. Comparison of the tumor uptake for ${ }^{99 m} T c-P-R G D_{2},{ }^{99 m} T c-3 G-R G D_{2},{ }^{99 m} T c-3 P-R G D_{2}$ and ${ }^{99 m} T c-R G D_{4}$ in the athymic nude mice bearing MDA-MB-435 breast cancer xenografts.

Table 2. Integrin $\alpha_{v} \beta_{3}$ binding data for cyclic RGD peptides and their corresponding HYNIC and DOTA conjugates against ${ }^{125}$-echistatin bound to the $\alpha_{v} \beta_{3}$-positive U87MG human glioma cells.

\begin{tabular}{|c|c|c|}
\hline Compound & $\mathrm{IC}_{50}(\mathrm{nM})$ & Radiotracer \\
\hline c(RGDyK) & $458 \pm 45$ & \\
\hline HYNIC-G-RGD & $358 \pm 8$ & [99mTc(HYNIC-G-RGD)(tricine)(TPPTS)] \\
\hline HYNIC-P-RGD & $452 \pm 11$ & [99mTc(HYNIC-P-RGD)(tricine)(TPPTS)] \\
\hline HYNIC-RGD 2 & $112 \pm 21$ & [99mTc(HYNIC-RGD 2 (tricine)(TPPTS)] \\
\hline HYNIC-P-RGD 2 & $84 \pm 7$ & [99mTc(HYNIC-P-RGD 2 (tricine)(TPPTS)] \\
\hline HYNIC-2G-RGD 2 & $60 \pm 4$ & [99mTc(HYNIC-2G-RGD 2 (tricine)(TPPTS)] \\
\hline HYNIC-2P-RGD 2 & $52 \pm 7$ & [99mTc(HYNIC-2P-RGD 2 )(tricine)(TPPTS)] \\
\hline HYNIC-3G-RGD 2 & $61 \pm 2$ & [99mTc(HYNIC-3G-RGD 2 (tricine)(TPPTS)] \\
\hline HYNIC-3P-RGD ${ }_{2}$ & $62 \pm 5$ & [99mTc(HYNIC-3P-RGD 2 )(tricine)(TPPTS)] \\
\hline 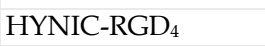 & $7 \pm 2$ & [99mTc(HYNIC-RGD 4 )(tricine)(TPPTS)] \\
\hline DOTA-RGD 2 & $102 \pm 5$ & ${ }^{64} \mathrm{Cu}($ DOTA-RGD 2$) /{ }^{111} \operatorname{In}($ DOTA-RGD 2$)$ \\
\hline DOTA-3G3-RGD 2 & $74 \pm 3$ & ${ }^{64} \mathrm{Cu}($ DOTA-3G-RGD 2$) /{ }^{111} \mathrm{In}\left(\mathrm{DOTA}-3 \mathrm{G}-\mathrm{RGD}_{2}\right)$ \\
\hline DOTA-3PEG 4 - RGD $_{2}$ & $62 \pm 6$ & ${ }^{64} \mathrm{Cu}\left(\mathrm{DOTA}-3 \mathrm{P}-\mathrm{RGD}_{2}\right) /{ }^{111} \mathrm{In}\left(\mathrm{DOTA}-3 \mathrm{P}-\mathrm{RGD}_{2}\right)$ \\
\hline DOTA-RGD $_{4}$ & $10 \pm 2$ & ${ }^{64} \mathrm{Cu}($ DOTA-RGD 4$) /{ }^{111} \operatorname{In}($ DOTA-RGD 4$)$ \\
\hline NOTA-RGD 2 & $100 \pm 3$ & ${ }^{68} \mathrm{Ga}\left(\mathrm{NOTA}-\mathrm{RGD}_{2}\right)$ \\
\hline NOTA-2G $-\mathrm{GGD}_{2}$ & $66 \pm 4$ & ${ }^{68} \mathrm{Ga}\left(\mathrm{NOTA}-2 \mathrm{G}-\mathrm{RGD}_{2}\right)$ \\
\hline NOTA-2PEG $4-\mathrm{RGD}_{2}$ & $54 \pm 2$ & ${ }^{68} \mathrm{Ga}\left(\mathrm{NOTA}-2 \mathrm{P}-\mathrm{RGD}_{2}\right)$ \\
\hline
\end{tabular}


Impact of radiometal chelate on tumor uptake and pharmacokinetics. Shi et al $[180,181]$ also prepared the cyclic RGD conjugates: $\mathrm{MAG}_{2}-3 \mathrm{P}-\mathrm{RGD}_{2}$ and $\mathrm{MAG}_{2}-3 \mathrm{G}-\mathrm{RGD}_{2}$. It was found that ${ }^{99} \mathrm{~m} \mathrm{TcO}\left(\mathrm{MAG}_{2}-3 \mathrm{P}-\mathrm{RGD}_{2}\right)$ had better tumor uptake than ${ }^{99 m}$ Tc-3P-RGD 2 [180], while their liver and kidney uptake was almost identical at $>60 \mathrm{~min}$ p.i. On the other hand, $99 \mathrm{mTcO}\left(\mathrm{MAG}_{2}-3 \mathrm{G}-\mathrm{RGD}_{2}\right)$ had the same tumor uptake as ${ }^{99 m T c}-3 \mathrm{G}-\mathrm{RGD}_{2}$ at $<60 \mathrm{~min}$ p.i., but its liver and kidney uptake was much lower than that of 99mTc-3G-RGD 2 [181]. Among 99mTc-labeled cyclic RGD dimers evaluated in the U87MG glioma-bearing model, ${ }^{99} \mathrm{mTcO}\left(\mathrm{MAG}_{2}-3 \mathrm{P}-\mathrm{RGD}_{2}\right)$ has the highest glioma uptake ( $15 \%$ ID/g over 2 h study period) while ${ }_{99} \mathrm{mcO}\left(\mathrm{MAG}_{2}-3 \mathrm{G}-\mathrm{RGD}_{2}\right.$ ) has the best tumor/kidney $(2.49 \pm 0.25)$ and tumor/liver $(8.29 \pm 1.50)$ ratios at 120 min p.i. Obviously, replacing [99mTc(HYNIC)(tricine)(TPPTS)] (M.W. $=\sim 1000$ Daltons) with ${ }^{99} \mathrm{mTCO}\left(\mathrm{MAG}_{2}\right)$ (M.W. $=\sim 350$ Daltons) had a significant impact on both tumor uptake and pharmacokinetics of $99 \mathrm{~m} T \mathrm{c}$ radiotracers. In contrast, substituting the bulky [99m Tc(HYNIC)(tricine)(TPPTS)] with a much smaller and more hydrophilic ${ }^{111}$ In(DOTA) chelate had little impact on the radiotracer tumor uptake $[182,183]$. However, the liver and kidney uptake of ${ }^{111} \mathrm{In}\left(\mathrm{DOTA}-3 \mathrm{P}-\mathrm{RGD}_{2}\right.$ ) is significantly lower than that of ${ }^{99 \mathrm{~m}} \mathrm{Tc}-3 \mathrm{P}-\mathrm{RGD}_{2}$, probably due to higher hydrophilicity of ${ }^{111} \operatorname{In}(\mathrm{DOTA})$ [82]. Similar conclusion could be made by directly comparing

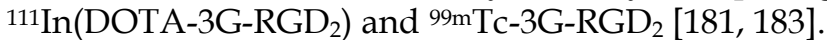

${ }^{111} \mathrm{In}\left(\mathrm{DOTA}-3 \mathrm{P}-\mathrm{RGD}_{2}\right)$ and ${ }^{64} \mathrm{Cu}(\mathrm{DOTA}-3 \mathrm{P}-$ $\mathrm{RGD}_{2}$ ) share the same DOTA-conjugate. The tumor uptake of ${ }^{111} \operatorname{In}\left(\right.$ DOTA-3P-RGD ${ }_{2}$ ) was very close to that of ${ }^{64} \mathrm{Cu}\left(\mathrm{DOTA}-3 \mathrm{P}-\mathrm{RGD}_{2}\right)[176,182]$. They also have a similar uptake in normal organs. For example, the kidney uptake of ${ }^{111} \operatorname{In}($ DOTA-3P-RGD 2 ) was compared well with that of ${ }^{64} \mathrm{Cu}\left(\mathrm{DOTA}-3 \mathrm{P}-\mathrm{RGD}_{2}\right)$ within the experimental errors. The liver uptake of ${ }^{111} \mathrm{In}\left(\mathrm{DOTA}-3 \mathrm{P}-\mathrm{RGD}_{2}\right)$ was $2.52 \pm 0.57 \% \mathrm{ID} / \mathrm{g}$ at 30 min and $1.61 \pm 0.06 \% \mathrm{ID} / \mathrm{g}$ at $240 \mathrm{~min}$ p.i., while ${ }^{64} \mathrm{Cu}\left(\mathrm{DOTA}-3 \mathrm{P}-\mathrm{RGD}_{2}\right)$ had the liver uptake of $2.80 \pm$ $0.35 \% \mathrm{ID} / \mathrm{g}$ at $30 \mathrm{~min}$ p.i. and $1.87 \pm 0.51 \% \mathrm{ID} / \mathrm{g}$ at 240 min p.i. These data suggest that the radiometal $\left({ }^{64} \mathrm{Cu}\right.$ vs. ${ }^{111} \mathrm{In}$ ) has little impact on the radiotracer tumor uptake and excretion kinetics, probably due to the overwhelmingly large size of the dimeric RGD peptides as compared to that of the radiometal chelate. The same conclusion was also made by directly comparing the uptake in tumor and normal organs for ${ }^{111} \mathrm{In}\left(\mathrm{DOTA}-3 \mathrm{G}-\mathrm{RGD}_{2}\right)$ [183] and ${ }^{64} \mathrm{Cu}(\mathrm{DOTA}-3 \mathrm{G}-$ $\mathrm{RGD}_{2}$ ) [176].

Integrin $\alpha_{v} \beta_{3}$ and $R G D$ specificity. The $\mathrm{a}_{\mathrm{v}} \beta_{3}$-specificity of ${ }^{99} \mathrm{~m} \mathrm{TcO}\left(\mathrm{MAG}_{2}-3 \mathrm{P}-\mathrm{RGD}_{2}\right)$ and
${ }^{111} \operatorname{In}($ DOTA-3P-RGD 2 ) was demonstrated by the "blocking experiment" (Fig. 9).
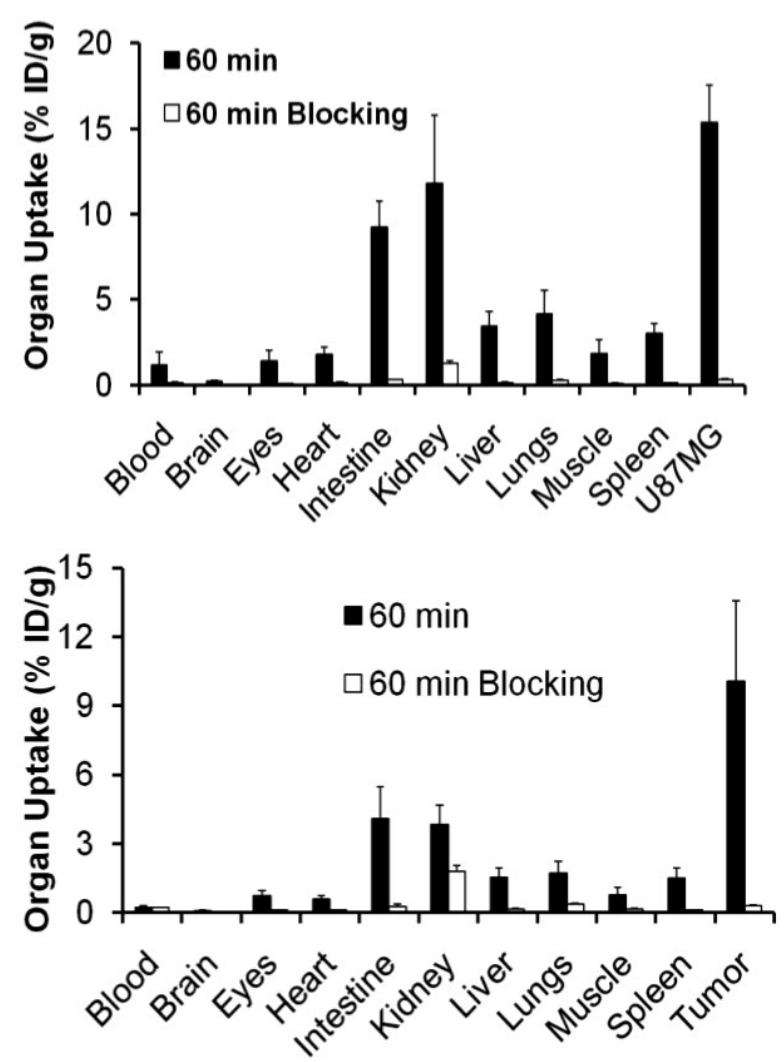

Figure 9. Comparison of the 60-min biodistribution data in the athymic nude mice bearing U87MG glioma xenografts in the absence/presence of excess $R G D_{2}$ to demonstrate its $\alpha_{v} \beta_{3}$-specificity for ${ }^{99 m} \mathrm{TcO}\left(\mathrm{MAG}_{2}-3 \mathrm{P}-\mathrm{RGD}_{2}\right)$ (top) and "I'In(DOTA-3P-RGD ) (bottom). The blockage of their tumor uptake indicates that the radiolabeled cyclic RGD dimers are $\alpha_{\mathrm{v}} \beta_{3}$-specific.

The blockage of their tumor uptake indicates that they are $\alpha_{v} \beta_{3}$-specific $[181,182]$. The uptake blockage in eyes, intestine, lungs, liver and spleen suggests that their uptake in these organs is partially $\alpha_{\mathrm{v}} \beta_{3}$-mediated. The RGD-specificity of

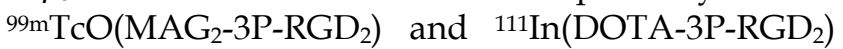
was demonstrated by comparing their 60-min uptake with that of $99 \mathrm{mTcO}\left(\mathrm{MAG}_{2}-3 \mathrm{P}-\mathrm{RGK}_{2}\right)$ and ${ }^{111} \mathrm{In}\left(\mathrm{DOTA}-3 \mathrm{P}-\mathrm{RGK}_{2}\right.$ ), respectively. The dimeric peptide $3 \mathrm{P}-\mathrm{RGK}_{2}$ has the same molecular weight as $3 P-R G D_{2}$; but they have different peptide sequence $[181,182]$. As expected, replacing the two c(RGDfK) moieties in $3 \mathrm{P}-\mathrm{RGD}_{2}$ with two $\mathrm{c}(\mathrm{RGKfD})$ motifs resulted in a much lower $\alpha_{v} \beta_{3}$ binding affinity of MAG $_{2}-3$ P-RGK $2 ~\left(I_{50}=711 \pm 128 \mathrm{nM}\right)$ and DOTA-3P-RGK $2\left(\mathrm{IC}_{50}=715 \pm 45 \mathrm{nM}\right)$ than that of 
$\mathrm{MAG}_{2}-3 \mathrm{P}-\mathrm{RGD}_{2} \quad\left(\mathrm{IC}_{50}=3.9 \pm 0.4 \mathrm{nM}\right)$ and DOTA-3P-RGD $\quad\left(\mathrm{IC}_{50}=1.3 \pm 0.3 \quad \mathrm{nM}\right)$ against ${ }^{125} \mathrm{I}-\mathrm{c}$ (RGDyK) bound to the U87MG glioma cells. As a result, $\quad 99 \mathrm{mTcO}\left(\mathrm{MAG}_{2}-3 \mathrm{P}-\mathrm{RGK}_{2}\right)$ and ${ }^{111}$ In(DOTA-3P-RGK 2 ) had much lower uptake as compare to that of $99 \mathrm{~m} \mathrm{TcO}\left(\mathrm{MAG}_{2}-3 \mathrm{P}-\mathrm{RGD}_{2}\right)$ and
${ }^{111}$ In(DOTA-3P-RGD $)$ in both tumor and normal organs (Fig. 10). These data strongly suggest that the localization of ${ }^{99} \mathrm{~m}_{\mathrm{C}} \mathrm{O}\left(\mathrm{MAG}_{2}-3 \mathrm{P}-\mathrm{RGD}_{2}\right)$ and ${ }^{111}$ In(DOTA-3P-RGD $)$ in the tumor is indeed based on interactions between RGD motifs and $\alpha_{v} \beta_{3}[181,182]$.
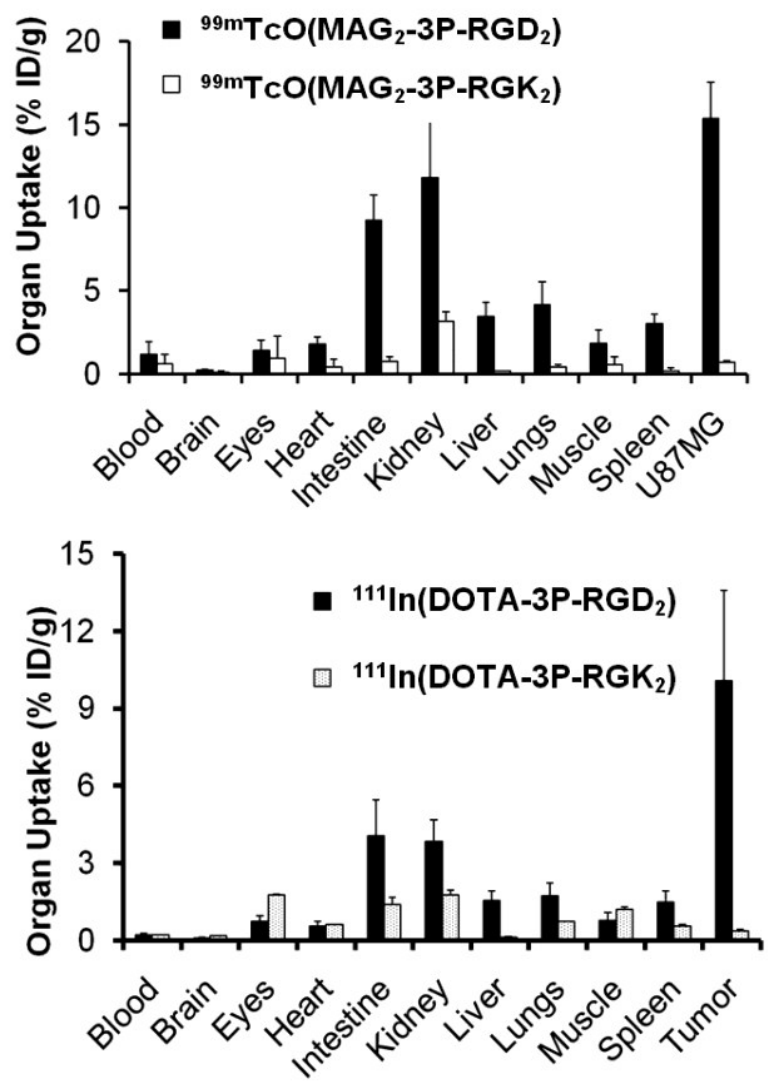

Figure 10. Comparison of biodistribution data of ${ }^{99 \mathrm{~m}} \mathrm{TcO}\left(\mathrm{MAG}_{2}-3 \mathrm{P}-\mathrm{RGD}_{2}\right) /{ }^{99 \mathrm{~m}} \mathrm{TcO}\left(\mathrm{MAG}_{2}-3 \mathrm{P}-\mathrm{RGK}_{2}\right)$ and '"'In(DOTA-3P-RGD $) / 1 "$ In(DOTA-3P-RGK ${ }_{2}$ ) in athymic nude mice bearing U87MG glioma xenografts at 60 min post-injection. The low tumor uptake for ${ }^{99 \mathrm{~m}} \mathrm{TcO}\left(\mathrm{MAG}_{2}-3 \mathrm{P}-\mathrm{RGK}_{2}\right)$ and ${ }^{\prime \prime} \operatorname{In}\left(\mathrm{DOTA}-3 \mathrm{P}-\mathrm{RGK}_{2}\right)$ indicates that the radiolabeled cyclic RGD dimers are RGD-specific.

Multimeric $\neq$ multivalent. On the basis of the in vitro $\alpha_{v} \beta_{3}$ binding assays and the ex-vivo biodistribution data, it becomes quite clear that $3 \mathrm{P}-\mathrm{RGD}_{2}$, $3 \mathrm{G}-\mathrm{RGD}_{2}$ and $\mathrm{RGD}_{4}$ are bivalent in binding to the $\mathrm{a}_{\mathrm{v}} \beta_{3}$. However, it remains unclear if $\mathrm{RGD}_{4}$ will become tetravalent if a number of $\mathrm{G}_{3}$ or $\mathrm{PEG}_{4}$ linkers are incorporated between its four cyclic RGD motifs. To answer this fundamental question, two DOTA-conjugated cyclic peptide RGD tetramers (Fig. 11: $6 \mathrm{P}-\mathrm{RGD}_{4}$ and $6 \mathrm{G}-\mathrm{RGD}_{4}$ ) have been successfully prepared [183, 184]. Fig. 12 compares the tumor uptake of ${ }^{111}$ In-labeled RGD dimers $\left(3 \mathrm{P}-\mathrm{RGD}_{2}\right.$ and 3G-RGD 2 ) and tetramers (6P-RGD 4 and $6 \mathrm{G}-\mathrm{RGD}_{4}$ ) in the athymic nude mice bearing U87MG glioma xeno- grafts. The fact that ${ }^{111} \operatorname{In}\left(\mathrm{DOTA}-3 \mathrm{P}-\mathrm{RGD}_{2}\right)$ and ${ }^{111}$ In(DOTA-6P-RGD 4 ) shared a very similar initial tumor uptake within the experimental errors suggests that $6 \mathrm{P}-\mathrm{RGD}_{4}$ and $6 \mathrm{G}-\mathrm{RGD}_{4}$ may not be truly tetravalent $[183,184]$.

As discussed previously, both bivalency and the locally enhanced RGD concentration contribute to the high $\alpha_{v} \beta_{3}$ binding affinity of multimeric RGD peptides. The concentration factor exists in all multimeric RGD peptides regardless of spacers or linkers. The key for bivalency is the distance between two RGD motifs. For example, this distance in $3 \mathrm{P}^{-R_{G}} \mathrm{D}_{2}(38$ bonds) and 3G-RGD 2 (26 bonds) is long enough for them to achieve bivalency, which leads to higher $\alpha_{v} \beta_{3}$ 
binding affinity of DOTA-3P-RGD 2 and DOTA-3G-RGD 2 than that of DOTA-RGD 2 (Table 2), and higher tumor uptake of ${ }^{111} \operatorname{In}\left(\mathrm{DOTA}-3 \mathrm{P}-\mathrm{RGD}_{2}\right)$ and ${ }^{111} \mathrm{In}\left(\mathrm{DOTA}-3 \mathrm{G}-\mathrm{RGD}_{2}\right)$ than that of ${ }^{111} \mathrm{In}\left(\mathrm{DOTA}-\mathrm{P}-\mathrm{RGD}_{2}\right)$ [139]. In contrast, the concentration factor might be responsible for the longer tumor retention times (Fig. 13) of ${ }^{111} \mathrm{In}\left(\mathrm{DOTA}-6 \mathrm{G}-\mathrm{RGD}_{4}\right.$ ) as compared to that of ${ }^{111} \operatorname{In}\left(\mathrm{DOTA}-3 \mathrm{G}-\mathrm{RGD}_{2}\right)$. Even if 6P-RGD 4 and $6 \mathrm{G}-\mathrm{RGD}_{4}$ are not tetravalent, the mere presence of two extra RGD motifs definitely helps to improve the radiotracer tumor retention time, which may become important for ${ }^{90} \mathrm{Y}$ and ${ }^{177} \mathrm{Lu}$ radiotracers, which have great potential for systemic radiotherapy of the $\alpha_{v} \beta_{3}$-positive tumors.

It must be noted that the ability of a multimeric RGD peptide to achieve bivalency also depends on the $\alpha_{v} \beta_{3}$ density. If the $\alpha_{v} \beta_{3}$ density is very high, the distance between two neighboring $a_{v} \beta_{3}$ sites will be short, which makes it easier for the multimeric cyclic RGD peptide to achieve the bivalency. If the $\alpha_{v} \beta_{3}$ density is very low, the distance between two neighboring $a_{v} \beta_{3}$ sites will be very long, and it might be more difficult for the same multimeric cyclic RGD peptide to achieve simultaneous $\alpha_{\mathrm{v}} \beta_{3}$ binding.<smiles>CC(C)(C)O[R6](=O)O[R6](=O)O[Na]</smiles><smiles>[R6]O[R6](=O)O[R6](=O)O[Na]</smiles>

Figure I I. DOTA-conjugated cyclic RGD tetramers: DOTA-6P-RGD 4 and DOTA-6G-RGD . 

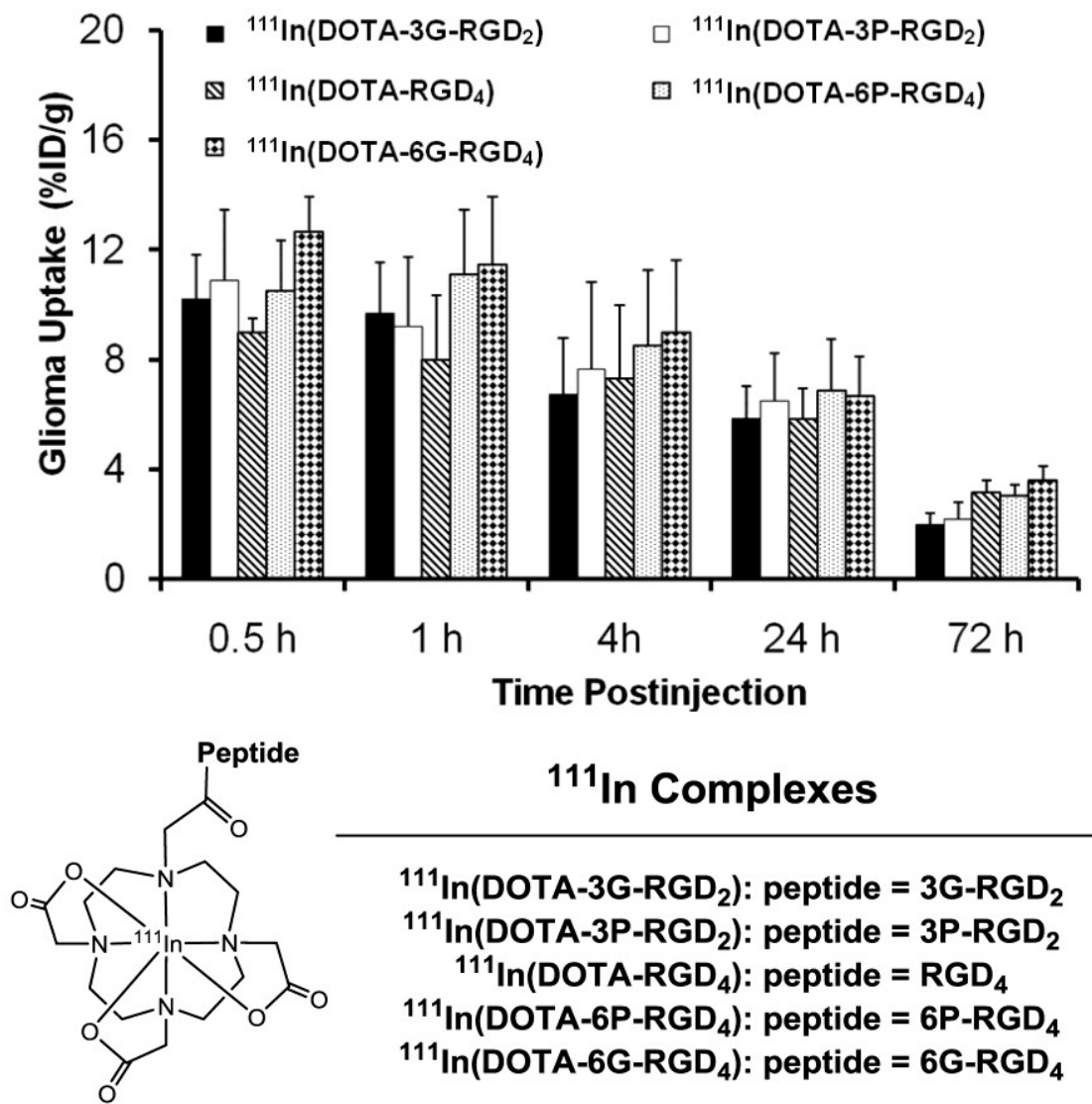

${ }^{111}$ In Complexes

$$
\begin{aligned}
& { }^{111} \operatorname{In}(\text { DOTA-3G-RGD }): \text { peptide }=3 \text { G-RGD } 2 \\
& { }^{111} \operatorname{In}(\text { DOTA-3P-RGD }): \text { peptide }=3 P-R \mathrm{D}_{2} \\
& { }^{111} \operatorname{In}(\text { DOTA-RGD }): \text { peptide }=\text { RGD }_{4} \\
& { }^{111} \operatorname{In}\left(\text { DOTA-6P-RGD }{ }_{4}\right): \text { peptide }=6 \mathrm{P}-\mathrm{RGD}_{4} \\
& { }^{111} \operatorname{In}(\text { DOTA-6G-RGD } 4 \text { ): peptide }=6 \text { G-RGD }
\end{aligned}
$$

Figure 12. Direct comparison of the tumor uptake of the "'In-labeled cyclic RGD dimers (3P-RGD 2 and $\left.3 G-R G D_{2}\right)$ and tetramers $\left(R_{G D}, 6 P-R G D_{4}\right.$ and $\left.6 G-R G D_{4}\right)$ in athymic nude mice bearing U87MG human glioma xenografts.

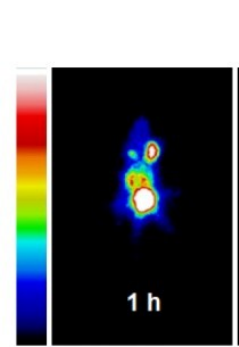

${ }^{111} \operatorname{In}($ DOTA-6G-RGD 4$)$

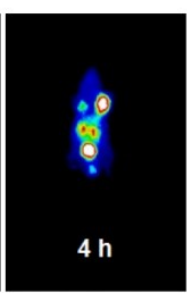

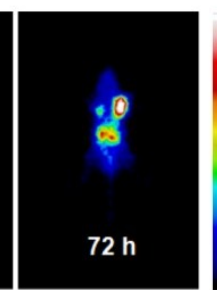

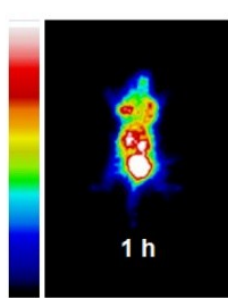

${ }^{111} \operatorname{In}($ DOTA-3G-RGD $)$
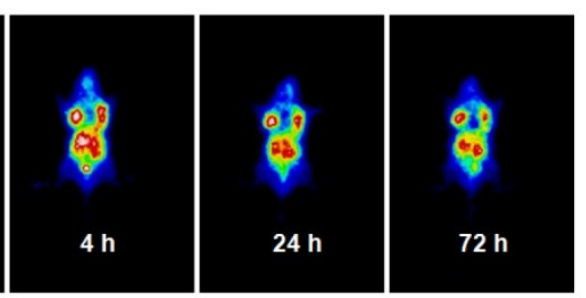

Figure 13. The whole-body planar images of the tumor-bearing mice administered with $\sim 100 \mu \mathrm{Ci}$ of "'In(DOTA-6G-RGD ${ }_{4}$ ) and "'In(DOTA-3G-RGD $)$ at I, 4, 24 and $72 \mathrm{~h}$ p.i. The concentration factor is responsible for the longer tumor retention time of ${ }^{\prime \prime \prime} \operatorname{In}\left(\right.$ DOTA-6G-RGD ${ }_{4}$ ) (left) as compared to that of ${ }^{\prime \prime \prime} \operatorname{In}($ DOTA-3G-RGD $)$ (right).

\section{3. $\alpha_{\text {IIb }} \beta_{3}$-TARGETED RADIOTRACERS FOR THROMBOSIS IMAGING}

Cardiovascular diseases and vulnerable plaque. Cardiovascular diseases are the most frequent causes of death in the Western world. Atherosclerosis is the main cause of coronary and peripheral arterial diseases [185-189]. Atherosclerosis is a chronic and progressive systemic disease, with a long asymptomatic phase, characterized by accumulation of lipids, inflammatory cells and connective tissue within the intima of arterial wall $[187,189]$. The initial pathologic 
abnormality is the fatty streak, due to accumulation of lipoproteins and macrophages, which may develop into a mature atherosclerotic plaque, with a lipid core bounded on its lumen side by a fibrous cap containing vascular smooth muscle cells and connective tissue. Atherosclerosis remains clinically silent until the lesion can expand to the point at which it limits flow, producing symptoms of reversible ischemia, such as angina, during periods of high demand [187-192]. Alternatively, the fibrous plaque can erode or rupture, resulting in the exposure of subendothelial collagen and lipid [187, 190], which leads to activation of platelets and clotting cascade proteins. Platelet activation upregulates $\alpha_{\mathrm{IIb}} \beta_{3}$ (or glycoprotein IIb/IIIa) on the platelet surface which, when stimulated, promote platelet aggregation [193-199]. Activation of clotting factor proteins VII and XI results in production of thrombin, fibrinogen, and fibrin through the so-called extrinsic and intrinsic coagulation pathways, respectively. The result is the formation of thrombus composed of both fibrin and platelets. The consequences of plaque rupture range from complete lysis of the thrombus by endogenous fibrinolytic pathways with subsequent healing of the fibrous cap and overlying endothelium to the unchecked thrombosis and complete lumen occlusion. Such an event can range from being clinically silent at one extreme through precipitation of an acute vascular event, such as unstable angina, myocardial infarction or stroke, to sudden death at the other extreme [188-190]. It is the rupture of plaque and formation of a thrombus that causes the most serious complications of atherosclerosis, such as acute coronary syndromes and stroke [187, 189, 190]. In fact, the plaque rupture is responsible for $76 \%$ of all fatal heart attacks caused by coronary thrombosis worldwide [187-190, 196-204]. Thus, early detection of the processes underlying progressive plaque destabilization for the purpose of identifying the patients in whom rupture of a vulnerable plaque is likely to result in a clinical event, is of the utmost importance [201-205]. Since the disruption of atherosclerotic plaques is known to initiate thrombus formation leading to thrombotic and thromboembolic events, it has been suggested that the thrombogenicity of atherosclerotic plaques is one of the most promising approaches to detecting vulnerable plaques [189, 190, 196-205]. From this point of view, the accurate detection of the intra-arterial thrombus noninvasively could have significant diagnostic and prognostic implications [201-205].

Deep vein thrombosis (DVT). DVT is the formation of blood clots in veins and is also known as venous thromboembolism [14,65, 206]. DVT occurs when a thrombus forms in one of large veins in the lower extremities, leading to partially or completely blocked blood circulation. The condition may result in health complications, such as a pulmonary embolism (PE) or death if not diagnosed and treated effectively. A majority of DVT patients will experience PE $(\sim 30 \%$ are symptomatic, and $40 \%$ are asymptomatic and at high risk) because the blood clot is unstable and can travel to, and lodges in, the lungs. More than 1 million people in the United States suffer from DVT blood clots every year. Complications from DVT blood clots kill almost 300,000 people a year - more than AIDS and breast cancer combined [14, 206]. Thus, accurate early detection of DVT and PE is highly desirable so that various therapeutic regimens can be given.

Imaging arterial thrombi. To identify healthy subjects at risk for future cardiovascular events, a consensus of experts has recently defined criteria for the diagnosis of vulnerable plaques [190, 192]. Major criteria have been established to represent different aspects of the rupture-prone plaque. These include the calcified nodules, yellow appearance of the plaque, intraplaque hemorrhage, thrombogenicity, active inflammation and plaque injury. Further major criteria include a thin cap, a large lipid core, and luminal stenosis [190, 192, 203]. Although many imaging techniques are now clinically available for diagnosis of luminal narrowing, arterial occlusion and intramural hematoma [201-205], arterial thrombi are not reliably detected by current diagnostic methods. Coronary angiography remains the gold standard to assess vessel lumen narrowing. Other invasive techniques include intravascular coronary ultrasound, coronary angioscopy, intravascular elastography, elastography, thermography, or optical coherence tomography [201-205, 207]. These techniques can provide anatomic details of plaque size and composition, but they have the disadvantage of being invasive. MRI and CT have also been used for diagnosis of arterial thrombi; but these two modalities are anatomical and functional [208-213]. It is difficult to distinguish the "fresh" and "old" thrombi with MRI and CT. In contrast, nuclear imaging by SPECT and PET has the most potential to furnish functional information on biologic events which determine the risk of plaque rupture [201, 203, 205]. Besides their noninvasive nature, nuclear medicine techniques have the potential to evaluate important determinants of plaque vulnerability, taking into account specific cellular or biochemical changes that characterize these lesions. Radiolabeled monoclonal antibodies have been used to target fibrin or platelets on acute thrombi in humans [214-229], but they were expected to have very limited clinical usage due to their long blood circulation time. These limitations can be alleviated by 
using synthetic peptides that are much smaller and are cleared quickly from the blood circulation [230-232]. Examples of 99mTc-labeled small peptide radiotracers include $99 \mathrm{mTc}$-apcitide [233-239] and DMP444 [240-255], both of which target $\alpha_{\text {IIb }} \beta_{3}$ recep-

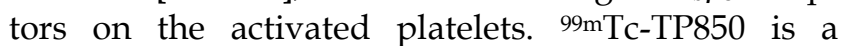
99mTc-labeled linear peptide targeting the fibrin component of thrombi [256]. The peptide-based radiotracers for thrombus imaging have been reviewed extensively [201-205, 257-265].

Imaging deep vein thrombosis. Contrast-enhanced venography remains the gold standard for diagnosis of DVT, but compression ultrasonography is the most common technique used to detect DVT in the lower extremities. Pooled analyses showed that ultrasonography has a sensitivity of $96 \%$ and a specificity of $98 \%$ for proximal vein thrombosis. The primary limitation of these diagnostic procedures is that neither technique can distinguish between chronic and unstable thrombi [14, 207, 259]. Both contrast venography and ultrasonography are imaging procedures that detect changes in venous anatomy that are caused by the intraluminal thrombus that is sufficiently formed either to reduce vascular filling with contrast medium or to resist compression. However, these procedures do not reflect the metabolic activity of the clot, and therefore, they may overestimate the presence of active clots. The sensitivity of ultrasonography is also limited by disease-related and technical factors. An alternative approach for diagnosis of acute DVT is to detect a molecular marker that is not present in old, organized DVT.

${ }^{99 m} T c$-apcitide: approved for imaging DVT. One of the important components of clotting process is platelet activation, which leads to the expression of $\alpha_{\mathrm{IIb}} \beta_{3}$ receptors that bind fibrinogen and promote platelet-platelet interaction, resulting in platelet aggregation and the formation of a secure plug. Many synthetic peptides targeting the $\alpha_{\mathrm{IIb}} \beta_{3}$ on activated platelets have been successfully radiolabeled with $99 \mathrm{mT}$. Because of their small size, these radiotracers often have very rapid clearance from the blood circulation. For example, $99 \mathrm{mTc}-\mathrm{P} 280$ (Fig. 14: 99mTc-apcitide) was the first RGD-mimicking peptide studied in humans [233]. ${ }^{99 \mathrm{~m} T \mathrm{Tc}-a p c i t i d e}$ was shown to specifically bind the $\alpha_{\mathrm{IIb}} \beta_{3}\left(\mathrm{IC}_{50}=0.20 \pm 0.11 \mu \mathrm{M}\right.$ for dog platelets as compared with $0.056 \pm 0.011 \mu \mathrm{M}$ for human platelets), and to selectively accumulate in fresh thrombi [233, 234]. Imaging studies in dogs also showed that the thrombus could be readily detected with ${ }^{99 m}$ Tc-apcitide [234]. A pilot study of 9 patients with carotid atherosclerosis showed the uptake in 11 of 18 carotid arteries after injection of $99 \mathrm{mTc}$-apcitide $[237,238]$. There was only a moderate correlation when compared with ultrasound findings. Bates et al enrolled patients with newly diagnosed first DVT and the patients with previous DVT [235]. It was found that the sensitivity and specificity of $99 \mathrm{mTc}$-apcitide were $92 \%$ and $86 \%$, respectively, for differentiating between the acute and chronic thrombus [235]. $99 \mathrm{mTc}$-apcitide had a sensitivity and specificity of $87 \%$ and $100 \%$, respectively, for the patients with DVT. These data have clearly demonstrated the potential of the $99 \mathrm{mTc}$-apcitide scintigraphy to address the important issues in terms of identifying the arterial lesions responsible for recent symptoms. However, 99mTc-apcitide was not particularly useful for detection of pulmonary embolism (PE) in $83 \%$ of the patients, most likely due to its low thrombus uptake and prolonged radioactivity accumulation in the blood pool and chest region [234]. ${ }^{99 \mathrm{~m} T \mathrm{Tc}-a p c i t i d e}$ has been approved by FDA (Food and Drug Administration) for imaging acute venous thrombosis in the lower extremities of patients. Apcitide (AcuTec ${ }^{\mathrm{TM}}$ ) is available commercially as a non-radioactive freeze-dried kit that can be labeled with $99 \mathrm{mTc}$ for clinical usage [236-239].

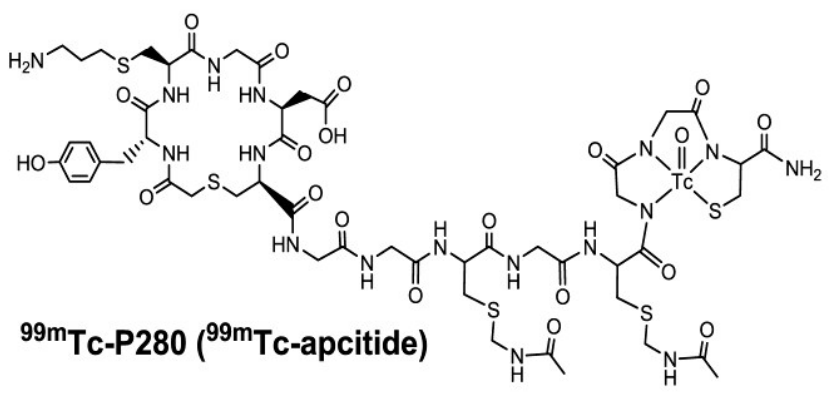

Figure 14. Structure of ${ }^{99 \mathrm{~m}} \mathrm{Tc}$-apcitide, a cyclic RGD peptide mimetic specifically binding to the $\alpha_{11 b} \beta_{3}$ expressed on fresh thrombi. ${ }^{99 \mathrm{~m}} \mathrm{Tc}$-apcitide has been approved by FDA for diagnosis of DVT in patients.

DMP444: clinically useful for imaging DVT. Activated platelets express $\alpha_{\mathrm{IIb}} \beta_{3}$ receptors which recognize proteins and small peptides bearing the RGD sequences while non-activated platelets express virtually no $\alpha_{\mathrm{IIb}} \beta_{3}$ receptors in their active conformation [240]. DMP728 and DMP757 (Fig. 2) were originally developed by DuPont Merck Pharmaceuticals as an antithrombotic agents and had very high selectivity and binding affinity for GPIIb/IIIa with IC $_{50}$ values in the nanomolar range against fibrinogen binding to the activated platelets [240]. Therefore, DMP728 and DMP757 are excellent biomolecules to target the fresh 
thrombi. Liu and coworkers at DuPont Medical Imaging used the 6-aminocaproic acid linker to connect DMP757 with a Tc-binding group, and to keep the Tc chelate separate from the cyclic RGD motif to minimize the impact of ${ }^{99 \mathrm{mTc}-l a b e l i n g}$ on the binding affinity for $\alpha_{\mathrm{IIb}} \beta_{3}$ [241-247]. The $\mathrm{N}_{2} \mathrm{~S}_{2}$ and $\mathrm{N}_{3}$ S-type of BFCs were used for ${ }^{99 m} \mathrm{mc}$-labeling of DMP757. It was found that BFCs had a significant impact on thrombus uptake and excretion kinetics of radiotracers [240-244]. DMP444 (Fig. 15: top) was prepared using HYNIC as the BFC, tricine and TPPTS as coligands. Among the ${ }^{99 \mathrm{mT}} \mathrm{Tc}$ radiotracers evaluated in various models, DMP444 had the best thrombus uptake with the highest thrombus/blood and thrombus/muscle ratios [246]. In the AV shunt model, DMP444 was rapidly incorporated into thrombi under both venous and arterial conditions [246]. In the canine DVT model, DMP444 was able to detect a growing venous thrombus (Fig. 15: bottom) as early as $15 \mathrm{~min}$ p.i. DMP444 has a slow blood clearance $(45 \%$ of the injected dose at $2 \mathrm{~h}$ ) and a high thrombus uptake (9.93 \pm $0.52 \% \mathrm{ID} / \mathrm{g}$ for arterial thrombi; and $2.86 \pm 0.37 \%$ ID/g for venous thrombi). Mitchel et al [250] tested the ability of DMP444 to identify platelet-rich thrombus in a canine model, and found that the thrombus radioactivity correlated well with thrombus weights. Kaul's group found that the microthroboembli can be detected after primary percutaneous transluminal coronary angioplasty (PTCA), and the infarct size was proportional to the magnitude and extent of microthroboembli [255]. Thrombus imaging during reperfusion may provide important information in the patients with acute myocardial infarction that may lead to better adjuvant therapy during PTCA. In the patients suspected with DVT, no clinically significant adverse effects were noted after administration of DMP444 [253]. Most of patients were taking Warfarin ${ }^{\circledR}$ (Coumadin ${ }^{\circledR}$ ) and heparin (n $=8)$ or Heparin ${ }^{\circledR}(n=1)$ and Warfarin ${ }^{\circledR}(n=1)$ alone at the time of imaging. The average time from the onset of symptoms to injection of DMP444 was 5 days (range 1 to 18 days). At $10-40$ min p.i., 8 of 10 patients demonstrated an area of the increased radioactivity that was clearly related to the abnormality as noted by ultrasound methods [253]. These preliminary data lead to the comprehensive Phase II clinical studies. It was concluded that DMP444 is very useful for noninvasive imaging of DVT with high sensitivity and specificity. In addition, it has also shown that the DMP444 SPECT allows in vivo visualization of infective endocarditis if it is performed within 1 to 2 weeks after antibiotic treatment [251]. A non-radioactive freeze-dried kit has been developed, and can be used for routine 99mTc-labeling in clinical settings [248, 266].
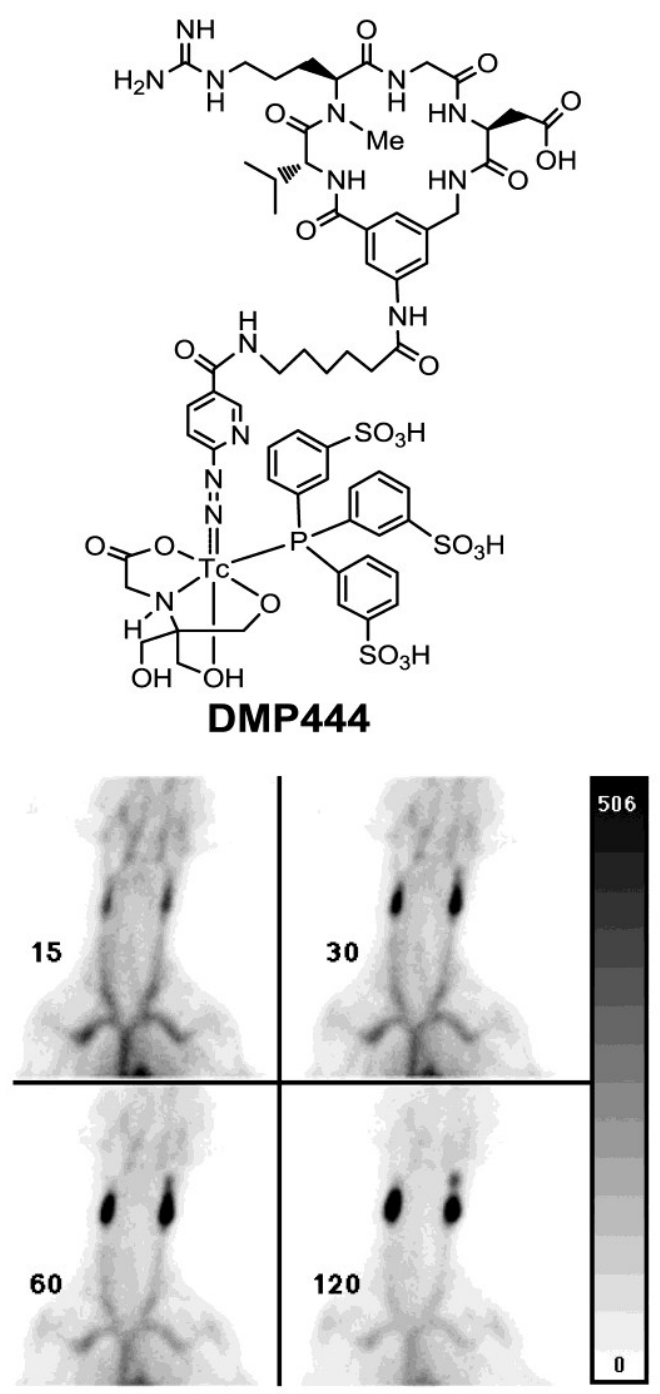

Figure I5. Top: Structure of DMP444; Bottom: DVT images of a dog administered with DMP444 at 15, 30, 60, and 120 min post-infusion. The bar to the right of the images indicates the scale from 0 (white) to 506 (greatest/black). The phase II clinical studies have demonstrated that DMP444 is clinically useful for imaging DVT.

\section{SUMMARY AND OUTLOOK}

Radiolabeled cyclic RGD peptides represent a new class of radiotracers for diagnosis of tumor or thrombosis, depending upon their selectivity for $\alpha_{v} \beta_{3}$ or $\alpha_{\mathrm{IIb}} \beta_{3}$. While cyclic RGD pentapeptides have high binding affinity and selectivity for $\alpha_{v} \beta_{3}$, the cyclic hexapeptides with one or more rigid aromatic rings tend to show high binding affinity and selectivity for $\alpha_{\text {IIb }} \beta_{3}$ over $\alpha_{v} \beta_{3} / \alpha_{v} \beta_{5}$. The $\alpha_{v} \beta_{3}$-targeted radiotracers have the potential for early detection of rapidly growing and metastatic tumor, and for monitoring the tumor growth, metastasis and therapeutic response 
by PET or SPECT [267, 268]. [18F]Galacto-RGD, [18F]AH111585 and 99mTc-NC100692 are currently under clinical investigations for noninvasive visualization of the $\alpha_{\mathrm{v}} \beta_{3}$-positive tumors in cancer patients. While the research efforts on $\alpha_{v} \beta_{3}$-targeted radiotracers have been focused on new RGD peptides with the improved $\alpha_{v} \beta_{3}$ affinity, the formulation development for routine preparation of radiotracers remains to be strengthened. It must be emphasized that the success of a new $\alpha_{v} \beta_{3}$-targeted radiotracer relies largely on its clinical availability at reasonable cost and capability to improve the quality of cancer patient's life. In this respect, the $99 \mathrm{mTc}$ radiotracers will offer significant advantages because of the nuclear properties of $99 \mathrm{mTc}$ for SPECT, easy availability of ${ }^{99} \mathrm{Mo}-{ }^{99 \mathrm{~m} T c}$ generators, and the kit formulation for routine preparation of $99 \mathrm{~m} \mathrm{Tc}$ radiotracers at low cost.

Increasing the RGD peptide multiplicity can significantly enhance their $\alpha_{v} \beta_{3}$ binding affinity, and improve tumor targeting ability of their radiotracers. However, the tumor selectivity is not substantially improved because the uptake of radiolabeled cyclic RGD peptide multimers in the intestine, liver and kidneys is also significantly increased. As a result, there is no significant advantage in using radiolabeled tetramers (such as $\mathrm{RGD}_{4}, 6 \mathrm{G}-\mathrm{RGD}_{4}$ and $6 \mathrm{P}-\mathrm{RGD}_{4}$ ) over their dimeric counterparts (such as $3 \mathrm{G}-\mathrm{RGD}_{2}$ and $3 P-R G D_{2}$ ) as diagnostic radiotracers with respect to the tumor selectivity or T/B ratios. Among the cyclic RGD dimers evaluated in different preclinical tumor-bearing animal models, 3G-RGD 2 and $3 P-R_{2} D_{2}$ are the best $\alpha_{v} \beta_{3}$-targeting biomolecules because their corresponding PET and SPECT radiotracers tend to have excellent tumor uptake with very high $\mathrm{T} / \mathrm{B}$ ratios. Recently, ${ }^{99 \mathrm{mT}} \mathrm{Tc}-3 \mathrm{P}-\mathrm{RGD}_{2}$ has been selected as a candidate for clinical evaluations because of its high tumor uptake, long tumor retention and high metabolic stability $[174,175]$.

It is important to emphasize that $\alpha_{\mathrm{v}} \beta_{3}$ is also over-expressed on the activated endothelial cells during wound healing and post-infarction remodeling, in rheumatoid arthritis and psoriatic plaque [269-271]. Thus, the $\alpha_{v} \beta_{3}$-targeted radiotracers developed for tumor imaging have been proposed for imaging myocardial angiogenesis. For example, recent studies clearly showed that the ${ }^{111}$ In-labeled nonpeptide $\alpha_{v} \beta_{3}$ antagonist (RP748) was able to image angiogenesis in the heart after myocardial infarction [271], and the radiotracer uptake in the infarct region was associated with the level of $\alpha_{v} \beta_{3}$ expression. The results from imaging studies also suggest that [18F]Galacto-RGD might be a powerful tool to distinguish between acute and chronic phases of T-cell me- diated immune responses [272]. These promising results give rise to the possibility of extending applications of the $\alpha_{\mathrm{v}} \beta_{3}$-targeted radiotracers from imaging tumor angiogenesis to detection of inflammatory processes, and to monitoring outcomes of therapeutic interventions in patients with cancer, myocardial infarction, and inflammation.

While the DVT can be detected by contrast-enhanced venography and compression ultrasonography, accurate detection of arterial thrombi and PE remains a significant challenge because of their small size and location. ${ }^{99 \mathrm{mTc}-a p c i t i d e ~ w a s ~ a p-~}$ proved for diagnosis of DVT; but its $\mathrm{T} / \mathrm{B}$ ratios are low due to its accumulation in the blood pool and chest region [246]. DMP444 has higher thrombus up-

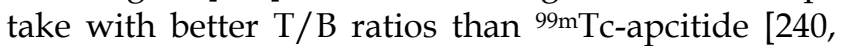
246]. However, its blood clearance rate is relatively slow, due to the lipophilic 6-aminocaproic linker and/or the highly charged ternary ligand system. Therefore, the focus of future research in this area should be directed towards developing more efficient radiotracers that have faster blood clearance and are useful for accurate detection of small thrombosis lesions in the coronary artery, as well as DVT and PE in patients. The "bivalency concept" developed for $\alpha_{\mathrm{v}} \beta_{3}$-targeted radiotracers may also apply to cyclic RGD hexapeptides to improve the $\alpha_{\mathrm{II}} \beta_{3}$-targeting capability. Since thrombus formation represents the final step in atherosclerosis progression, imaging with the $\alpha_{v} \beta_{3}$-targeted radiotracers may be able to not only identify those patients at high risk for cardiovascular events (death, myocardial infarction or stroke) not identified by routine clinical evaluation, but also characterize the lesion vulnerability in high-risk areas of the coronary vasculature. Once the lesion is determined to be of particularly high risk, novel local therapies such as intracoronary drug-eluting stents or local drug delivery with suitable drug-delivery balloon catheters could be justified. In addition, molecular imaging of arterial thrombi will help to select the individualized treatment strategies based on the molecular profile of vulnerable plaques identified in a particular patient.

\section{Acknowledgement}

The authors would like to thank Dr. Xiaoyuan Chen at the National Institute of Biomedical Imaging and Bioengineering (NIBIB), and Dr. Fan Wang at the Beijing University Medical Isotopes Research Center for their collaboration on $\mathrm{IC}_{50}$ values of multimeric cyclic RGD peptides. This work is supported, in part, by Purdue University and research grants: R01 CA115883 A2 (S.L.) from the National Cancer Institute 
(NCI) and DE-FG02-08ER64684 from the Department of Energy.

\section{Conflict of Interest}

The authors have declared that no conflict of interest exists.

\section{References}

1. Jurisson SS, Lydon JD. Potential technetium small molecule radiopharmaceuticals. Chem Rev 1999; 99: 2205-18.

2. Anderson CJ, Welch MJ. Radiometal-labeled agents (non-technetium) for diagnostic imaging. Chem Rev 1999; 99: 2219-34.

3. Liu S, Edwards DS. ${ }^{99 \mathrm{~m} T \mathrm{Tc}-l a b e l e d ~ s m a l l ~ p e p t i d e s ~ a s ~ d i a g n o s t i c ~}$ radiopharmaceuticals. Chem Rev 1999; 99: 2235-68.

4. Liu S, Edwards DS. Fundamentals of receptor-based diagnostic metalloradiopharmaceuticals. Top Curr Chem 2002; 222: 259-78.

5. Liu S. The role of coordination chemistry in the development of target-specific radiopharmaceuticals. Chem Soc Rev 2004; 33: 445-61.

6. Liu S, Edwards DS. Bifunctional chelators for therapeutic lanthanide radiopharmaceuticals. Bioconj Chem 2001; 12: 7-34.

7. Heppeler A, Froidevaux S, Eberle AN, Maecke HR. Receptor targeting for tumor localization and therapy with radiopeptides. Curr Med Chem 2000; 7: 971-94.

8. Kwekkeboom D, Krenning EP, de Jong M. Peptide receptor imaging and therapy. J Nucl Med 2000; 41: 1704-13.

9. Boerman OC, Oyen WJ, Corstens FH. Radio-labeled receptor-binding peptides: a new class of radiopharmaceuticals. Semin Nucl Med 2000; 30: 195-208.

10. Signore A, Annovazzi A, Chianelli M, Corsetti F, Van de Wiele C, Watherhouse RN. Peptide radiopharmaceuticals for diagnosis and therapy. Eur J Nucl Med 2001; 28: 1555-65.

11. Hoffman TJ, Quinn TP, Volkert WA. Radiometallated receptor-avid peptide conjugates for specific in vivo targeting of cancer cells. Nucl Med Biol 2001; 28: 527-39.

12. Langer M, Beck-Sickinger AG. Peptides as carrier for tumor diagnosis and treatment. Curr Med Chem Anticancer Agents 2001; 1: 71-93.

13. Behr TM, Gotthardt M, Barth A, Béhé M. Imaging tumors with peptide-based radioligands. Q J Nucl Med 2001; 45: 189-200.

14. Blum JE, Handmaker H. Small peptide radiopharmaceuticals in the imaging of acute thrombus. Curr Pharm Des 2002; 8: 1815-26.

15. Weiner RE, Thakur ML. Radiolabeled peptides in the diagnosis and therapy of oncological diseases. Appl Radiat Isot 2002; 57: 749-63.

16. de Jong M, Kwekkeboom D, Valkema R, Krenning EP. Radiolabelled peptides for tumour therapy: current status and future directions. Eur J Nucl Med Mol Imaging 2003; 30: 463-9.

17. Fichna J, Janecka A. Synthesis of target-specific radiolabeled peptides for diagnostic imaging. Bioconj Chem 2003; 14: 3-17.

18. Okarvi SM. Peptide-based radiopharmaceuticals: future tools for diagnostic imaging of cancers and other diseases. Med Res Rev 2004; 24: 357-97.

19. Schottelius M, Wester HJ. Molecular imaging targeting peptide receptors. Methods 2009; 48: 161-77.

20. Lee S, Xie J, Chen X. Peptide-based probes for targeted molecular imaging. Biochem 2010; 49: 1364-76.

21. Desgrosellier JS, Cheresh DA. Integrins in cancer: biological implications and therapeutic opportunities. Nat Rev Cancer 2010; 10: 9-22.

22. Venter JC, Adams MD, Myers EW, et al. The sequence of the human genome. Science 2001; 291: 1304-51.
23. Miyata S, Koshikawa N, Yasumitsu H, Miyazaki K. Trypsin stimulates integrin a5 $\beta 1$-dependent adhesion to fibronectin and proliferation of human gastric carcinoma cells through activation of proteinase-activated receptor-2. J Biol Chem 2000; 275: 4592-8.

24. Hollenbeck ST, Itoh H, Louie O, Faries PL, Liu B, Kent KC. Type I collagen synergistically enhances PDGF-induced smooth muscle cell proliferation through pp60 $0^{\text {src-dependent crosstalk }}$ between the $\alpha_{2} \beta_{1}$ integrin and PDGF $\beta$ receptor. Biochem Biophys Res Commun 2004; 325: 328-37.

25. Zhou X, Murphy FR, Gehdu N, Zhang J, Iredale JP, Benyon RC. Engagement of $\alpha_{v} \beta_{3}$ integrin regulates proliferation and apoptosis of hepatic stellate cells. J Biol Chem 2004; 279: 23996-4006.

26. Horton MA. Interactions of connective tissue cells with the extracellular matrix. Bone 1995; 17: 51S-53S.

27. Singh P, Reimer CL, Peters JH, Stepp MA, Hynes RO, Van De Water L. The spatial and temporal expression patterns of integrin $\alpha_{9} \beta_{1}$ and one of its ligands, the EIIIA segment of fibronectin, in cutaneous wound healing. J Invest Dermatol 2004; 123: 1176-81.

28. Chao JT, Meininger GA, Patterson JL, et al. Regulation of a7-integrin expression in vascular smooth muscle by injury-induced atherosclerosis. Am J Physiol Heart Circ Physiol 2004; 287: H381-9.

29. Antonov AS, Kolodgie FD, Munn DH, Gerrity RG. Regulation of macrophage foam cell formation by $\alpha_{v} \beta_{3}$ integrin: potential role in human atherosclerosis. Am J Pathol 2004; 165: 247-58.

30. Tsuji T. Physiological and pathological roles of a3 $\beta 1$ integrin. J Membr Biol 2004; 200: 115-32.

31. Guo W, Giancotti FG. Integrin signalling during tumour progression. Nat Rev Mol Cell Biol 2004; 5: 816-26.

32. Chung J, Yoon SO, Lipscomb EA, Mercurio AM. The Met receptor and $\alpha_{6} \beta_{4}$ integrin can function independently to promote carcinoma invasion. J Biol Chem 2004; 279: 32287-93.

33. Zheng DQ, Woodard AS, Fornaro M, Tallini G, Languino LR. Prostatic carcinoma cell migration via $\alpha_{v} \beta_{3}$ integrin is modulated by a focal adhesion kinase pathway. Cancer Res 1999; 59: 1655-64.

34. Zecchinon L, Fett T, Baise E, Desmecht D. Characterization of the caprine (Capra hircus) beta-2 integrin CD18-encoding cDNA and identification of mutations potentially responsible for the ruminantspecific virulence of Mannheimia haemolytica. Mol Membr Biol 2004; 21: 289-95.

35. Isberg RR, Van Nhieu GT. The mechanism of phagocytic uptake promoted by invasin-integrin interaction. Trends Cell Biol 1995; 5: 120-4.

36. Morris MA, Ley K. Trafficking of natural killer cells. Curr Mol Med 2004; 4: 431-8.

37. Reardon DA, Nabors LB, Stupp R, Mikkelsen T. Cilengitide: an integrin-targeting arginine-glycine-aspartic acid peptide with promising activity for glioblastoma multiforme. Expert Opin Investig Drugs 2008; 17: 1225-35.

38. Miller WH, Keenan RM, Willette RN, Lark MW. Identification and in vivo efficacy of small-molecule antagonists of integrin $\mathrm{a}_{\mathrm{v}} \beta_{3}$ (the vitronectin receptor). Drug Discov Today 2000; 5:397-408.

39. Burke PA, DeNardo SJ. Antiangiogenic agents and their promising potential in combined therapy. Crit Rev Oncol Hematol 2001; 39: 155-71.

40. Tucker GC. Integrins: molecular targets in cancer therapy. Curr Oncol Rep 2006; 8: 96-103.

41. Gottschalk KE, Kessler H. The structures of integrins and integrin-ligand complexes: Implications for drug design and signal transduction. Angew Chem Int Ed Engl 2002; 41: 3767-74.

42. Smith JW. Cilengitide Merck. Curr Opin Investig Drugs 2003; 4: 741-5. 
43. Nissinen L, Pentikäinen OT, Jouppila A, et al. A small-molecule inhibitor of integrin $\alpha_{2} \beta_{1}$ introduces a new strategy for antithrombotic therapy. Thromb Haemost 2010; 103: 387-97.

44. Lal H, Verma SK, Foster DM, et al. Integrins and proximal signaling mechanisms in cardiovascular disease. Front Biosci 2009; 14: 2307-34.

45. Stefanelli T, Malesci A, De La Rue SA, Danese S. Anti-adhesion molecule therapies in inflammatory bowel disease: touch and go. Autoimmun Rev 2008; 7: 364-9.

46. Hilden TJ, Nurmi SM, Fagerholm SC, Gahmberg CG. Interfering with leukocyte integrin activation-a novel concept in the development of anti-inflammatory drugs. Ann Med 2006; 38: 503-11.

47. Caswell PT, Vadrevu S, Norman JC. Integrins: masters and slaves of endocytic transport. Nat Rev Mol Cell Biol 2009; 10: 843-53.

48. Bennett JS, Berger BW, Billings PC. The structure and function of platelet integrins. J Thromb Haemost 2009; 7 (Suppl 1): 200-5.

49. Wegener KL, Campbell ID. Transmembrane and cytoplasmic domains in integrin activation and protein-protein interactions (review). Mol Membr Biol 2008; 25: 376-87.

50. Switala-Jelen K, Dabrowska K, Opolski A, Lipinska L, Nowaczyk M, Gorski A. The biological functions of $\beta 3$ integrins. Folia Biol (Praha) 2004; 50: 143-52.

51. Kren A, Baeriswyl V, Lehembre F, et al. Increased tumor cell dissemination and cellular senescence in the absence of $\beta_{1}$-integrin function. EMBO J 2007; 26: 2832-42.

52. Zutter MM, Santoro SA, Staatz WD, Tsung YL. Re-expression of the $\alpha_{2} \beta_{1}$ integrin abrogates the malignant phenotype of breast carcinoma cells. Proc Natl Acad Sci USA 1995; 92: 7411-5.

53. Nip J, Shibata H, Loskutoff DJ, Cheresh DA, Brodt P. Human melanoma cells derived from lymphatic metastases use integrin $\alpha_{v} \beta_{3}$ to adhere to lymph node vitronectin. J Clin Invest 1992; 90: 1406-13.

54. Slack-Davis JK, Atkins KA, Harrer C, Hershey ED, Conaway M. Vascular cell adhesion molecule-1 is a regulator of ovarian cancer peritoneal metastasis. Cancer Res 2009; 69: 1469-76.

55. Hazelbag S, Kenter GG, Gorter A, et al. Overexpression of the $\alpha_{v} \beta_{6}$ integrin in cervical squamous cell carcinoma is a prognostic factor for decreased survival. J Pathol 2007; 212: 316-24.

56. Bello L, Francolini $M$, Marthyn $P$, et al. $\alpha_{v} \beta_{3}$ and $\alpha_{v} \beta_{5}$ integrin expression in glioma periphery. Neurosurgery 2001; 49: 380-9.

57. Adachi $M$, Taki $T$, Higashiyama $M$, Kohno N, Inufusa $H$, Miyake M. Significance of integrin a5 gene expression as a prognostic factor in node-negative non-small cell lung cancer. Clin Cancer Res 2000; 6: 96-101.

58. Owens DM, Romero MR, Gardner C, Watt FM. Suprabasal $\alpha_{6} \beta_{4}$ integrin expression in epidermis results in enhanced tumourigenesis and disruption of TGF $\beta$ signalling. J Cell Sci 2003; 116: 3783-91.

59. Felding-Habermann B, Habermann R, Saldivar E, Ruggeri ZM. Role of $\beta 3$ integrins in melanoma cell adhesion to activated platelets under flow. J Biol Chem 1996; 271: 5892-900.

60. Bakewell SJ, Nestor P, Prasad S, et al. Platelet and osteoclast $\beta 3$ integrins are critical for bone metastasis. Proc Natl Acad Sci USA 2003; 100: 14205-10.

61. Kroll MH, Hellums JD, McIntire LV, Schafer AI, Moake JL. Platelets and shear stress. Blood 1996; 88: 1525-41.

62. Popma JJ, Berger P, Ohman EM, Harrington RA, Grines C, Weitz JI. Antithrombotic therapy during percutaneous coronary intervention: the Seventh ACCP Conference on Antithrombotic and Thrombolytic Therapy. Chest 2004; 126: 576S-99S.

63. Barman N, Bhatt DL. Antithrombotic therapy for percutaneous coronary intervention. Cardiol Clin 2006; 24: 175-99.
64. Ferrario M, Merlini PA, Lucreziotti S, et al. Antithrombotic therapy of unstable angina and non-Q-wave myocardial infarction. Int J Cardiol 1999; 68 (Suppl 1): S63-71.

65. Quinn MJ, Byzova TV, Qin J, Topol EJ, Plow EF. Integrin $\alpha_{I I b} \beta_{3}$ and its antagonism. Arterioscler Thromb Vasc Biol 2003; 23: 945-52.

66. Pfaff M, Tangemann K, Müller B, et al. Selective recognition of cyclic RGD peptides of NMR defined conformation by $\mathrm{a}_{\mathrm{IIb}} \beta_{3}$, $\alpha_{v} \beta_{3}$, and $\alpha_{5} \beta_{1}$ integrins. J Biol Chem 1994; 269: 20233-8.

67. D'Andrea LD, Del Gatto A, Pedone C, Benedetti E. Peptide-based molecules in angiogenesis. Chem Biol Drug Des 2006; 67: 115-26.

68. Gottschalk KE, Kessler H. The structures of integrins and integrin-ligand complexes: Implications for drug design and signal transduction. Angew Chem Int Ed Engl 2002; 41: 3767-74.

69. Gurrath M, Müller G, Kessler H, Aumailley M, Timpl R. Conformation/activity studies of rationally designed potent anti-adhesive RGD peptides. Eur J Biochem 1992; 210: 911-21.

70. Muller G, Gurrath M, Kessler H, Timpl R. Dynamic forcing, a method for evaluating activity and selectivity profiles of RGD (Arg-Gly-Asp) peptides. Angew Chem Int Ed Engl 1992; 31: 326-8.

71. Hersel U, Dahmen C, Kessler H. RGD modified polymers: biomaterials for stimulated cell adhesion and beyond. Biomaterials 2003; 24: 4385-415.

72. Haübner R, Gratias R, Diefenbach B, Goodman SL, Jonczyk A, Kessler H. Structural and functional aspect of RGD-containing cyclic pentapeptides as highly potent and selective integrin avß3 antagonist. J Am Chem Soc 1996; 118: 7461-72.

73. Giannis A, Rubsam F. Integrin antagonists and other low molecular weight compounds as inhibitors of angiogenesis: new drugs in cancer therapy. Angew Chem Int Ed Engl 1997; 36: 588-90.

74. Haubner R, Finsinger D, Kessler H. Stereoisomeric peptide libraries and peptidomimetics for designing selective inhibitors of the av $\beta 3$ integrin for a new cancer therapy. Angew Chem Int Ed Engl 1997; 36: 1375-89.

75. Drake CJ, Cheresh DA, Little CD. An antagonist of integrin av $\beta 3$ prevents maturation of blood vessels during embryonic neovascularization. J Cell Sci 1995; 108: 2655-61.

76. Aumailley M, Gurrath M, Müller G, Calvete J, Timpl R, Kessler H. Arg-Gly-Asp constrained within cyclic pentapeptides strong and selective inhibitors of cell adhension to vitronectin and laminin fragment P1. FEBS Lett 1991; 291: 50-4.

77. Boturyn D, Dumy P. A convenient access to av $\beta 3 /$ av $\beta 5$ integrin ligand conjugates: regioselective solid-phase functionalization of an RGD based peptide. Tetrahedron Lett 2001; 42: 2787-90.

78. Bach AC, Espina JR, Jackson SA, et al. Type II' to type I $\beta$-turn swap changes specificity for integrins. J Am Chem Soc 1996; 118: 293-4.

79. Harlow RL. The structure of water as organized in an RGD peptide crystal at $-80{ }^{\circ} \mathrm{C}$. J Am Chem Soc 1993; 115: 9838-9.

80. Saitoh H, Aungst BJ. Prodrug and analog approaches to improving the intestinal absorption of a cyclic peptide, GPIIb/IIIa receptor antagonist. Pharm Res 1997; 14: 1026-9.

81. Weber WA, Haubner R, Vabuliene E, Kuhnast B, Webster HJ, Schwaiger $M$. Tumor angiogenesis targeting using imaging agents. Q J Nucl Med 2001; 45: 179-82.

82. Costouros NG, Diehn FE, Libutti SK. Molecular imaging of tumor angiogenesis. J Cellular Biochem Suppl 2002; 39: 72-8.

83. Pearlman JD, Laham RJ, Post M, Leiner T, Simons M. Medical imaging techniques in the evaluation of therapeutic angiogenesis. Curr Pharm Design 2002; 8: 1467-96.

84. van de Wiele C, Oltenfreiter R, De Winter O, Signore A, Slegers $\mathrm{G}$, Dierckx RA. Tumor angiogenesis pathways: related clinical 
issues and implications for nuclear medicine imaging. Eur J Nucl Med 2002; 29: 699-709.

85. Liu S, Robinson SP, Edwards DS. Integrin av $\beta 3$ directed radiopharmaceuticals for tumor imaging. Drugs of the Future 2003; 28: 551-64.

86. Haubner R, Wester HJ. Radiolabeled tracers for imaging of tumor angiogenesis and evaluation of antiantiogenic therapies. Curr Pharm Des 2004; 10: 1439-55.

87. Liu S, Robinson SP, Edwards DS. Radiolabeled integrin av $\beta 3$ antagonists as radiopharmaceuticals for tumor radiotherapy. Top Curr Chem 2005; 252: 193-216.

88. Liu S. Radiolabeled multimeric cyclic RGD peptides as integrin av $\beta 3$-targeted radiotracers for tumor imaging. Mol Pharm 2006; 3: $472-87$.

89. Lim EH, Danhti N, Bednarski M, Li KCP. A review: Integrin av $\beta 3$-targeted molecular imaging and therapy in angiogenesis. Nanomedicine: Nanotechnology, Biology and Medicine 2005; 1: 110-4.

90. Meyer A, Auernheimer J, Modlinger A, Kessler H. Targeting RGD recognizing integrins: drug development, biomaterial research, tumor imaging and targeting. Curr Pharm Des 2006; 12: 2723-47.

91. Chen X. Multimodality imaging of tumor integrin av $\beta 3$ expression. Mini-Rev Med Chem 2006; 6: 227-34.

92. Haubner R. av $\beta 3$-integrin imaging: a new approach to characterize angiogenesis? Eur J Nucl Med Mol Imaging 2006; 33 : S54-S63.

93. Cai W, Chen X. Multimodality molecular imaging of tumor angiogenesis. J Nucl Med 2008; 49: 113-28S.

94. Beer AJ, Schwaiger M. Imaging of integrin av $\beta 3$ expression. Cancer Metastasis Rev 2008; 27: 631-44.

95. Cai W, Niu G, Chen X. Imaging of integrins as biomarkers for tumor angiogenesis. Curr Pharm Des 2008; 14: 2943-73.

96. Hsu AR, Chen X. Advances in anatomic, functional, and molecular imaging of angiogenesis. J Nucl Med 2008; 49: 511-4.

97. Liu S. Radiolabeled cyclic RGD peptides as integrin av $\beta 3$-targeted radiotracers: maximizing binding affinity via bivalency. Bioconj Chem 2009; 20: 2199-213.

98. Folkman J. Angiogenesis in cancer, vascular, rheumatoid and other disease. Nat Med 1995; 1: 27-31.

99. Mousa SA. Mechanisms of angiogenesis in vascular disorders: potential therapeutic targets. Drugs Fut 1998; 23: 51-60.

100.Carmeliet P. Mechanism of angiogenesis and arteriogenesis. Nat Med 2000; 6: 389-95.

101.Bogler O, Mikkelsen T. Angiogenesis in glioma: molecular mechanisms and roadblocks to translation. Cancer J 2003; 9: 205-13.

102.Folkman J. Role of angiogenesis in tumor growth and metastasis. Semin Oncol 2002; 29: 15-8.

103.Hwang R, Varner JV. The role of integrins in tumor angiogenesis. Hematol Oncol Clin North Am 2004; 18: 991-1006.

104.Bergers G, Benjamin LE. Tumorigenesis and the angiogenic switch. Nat Rev Cancer 2003; 3: 401-10.

105.Ferrara N. VEGF and the quest for tumor angiogenesis factors. Nat Rev Cancer 2002; 2: 795-803.

106.Nyberg P, Xie L, Kalluri R. Endogenous inhibitors of angiogenesis. Cancer Res 2005; 65: 3967-79.

107.Jin H, Varner J. Integrins: roles in cancer development and as treatment targets. Br J Cancer 2004; 90: 561-5.

108.Kumar CC. Integrin av $\beta 3$ as a therapeutic target for blocking tumor-induced angiogenesis. Curr Drug Targets 2003; 4: 123-31.

109. Brooks PC, Clark RAF, Cheresh DA. Requirement of vascular integrin av $\beta 3$ for angiogenesis. Science 1994; 264: 569-71.

110.Ruoslahti E, Pierschbacher MD. New perspectives in cell adhesion: RGD and integrins. Science 1987; 238: 491-7.
111.Friedlander M, Brooks PC, Shaffer RW, Kincaid CM, Varner JA, Cheresh DA. Definition of two angiogenic pathways by distinct av integrin. Science 1995; 270: 1500-2.

112.Horton MA. The av $\beta 3$ integrin "vitronectin receptor". Int J Biochem Cell Biol 1997; 29: 721-5.

113.Meitar D, Crawford SE, Rademaker AW, Cohn SL. Tumor angiogenesis correlates with metastatic disease, $\mathrm{N}$-myc-amplification, and poor outcome in human neuroblastoma. J Clinical Oncol 1996; 14: 405-14.

114.Gasparini G, Brooks PC, Biganzoli E, et al. Vascular integrin av $\beta 3$ : a new prognostic indicator in breast cancer. Clinical Cancer Res 1998; 4: 2625-34.

115.Albelda SM, Mette SA, Elder DE, et al. Integrin distribution in maliganant melanoma: association of the $\beta 3$ subunit with tumor progression. Cancer Res 1990; 50: 6757-64.

116.Falcioni R, Cimino L, Gentileschi MP, et al. Expression of $\beta 1, \beta 3$, $\beta 4$, and $\beta 5$ integrins by human lung carcinoma cells of different histotypes. Exp Cell Res 1994; 210: 113-22.

117.Sengupta S, Chattopadhyay N, Mitra A, Ray S, Dasgupta S, Chatterjee A. Role of av $\beta 3$ integrin receptors in breast tumor. J Exp Clin Cancer Res 2001; 20: 585-90.

118.Felding-Habermann B, Mueller BM, Romerdahl CA, Cheresh DA. Involvement of integrin av gene expression in human melanoma tumorigenicity. J Clin Invest 1992; 89: 2018-22.

119.Hood JD, Cheresh DA. Role of integrins in cell invasion and migration. Nat Rev Cancer 2002; 2: 91-100.

120.Schnell O, Krebs B, Wagner E, et al. Expression of integrin av $\beta 3$ in gliomas correlates with tumor grade and is not restricted to tumor vasculature. Brain Pathol 2008; 18: 378-86.

121.Zitzmann S, Ehemann V, Schwab M. Arginine-glycine-aspartic acid (RGD)-peptide binds to both tumor and tumor-endothelial cells in vivo. Cancer Res 2002; 62: 5139-43.

122.Van Hagen PM, Breeman WAP, Bernard HF, et al. Evaluation of a radiolabeled cyclic DTPA-RGD analog for tumor imaging and radionuclide therapy. Int J Cancer (Radiat Oncol Invest) 2000; 90: 186-98.

123.Sivolapenko GB, Skarlos D, Pectasides D, et al. Imaging of metastatic melanoma utilizing a technetium-99m labeled RGD-containing synthetic peptide. Eur J Nucl Med 1998; 25: 1383-9.

124.Haubner R, Wester HJ, Senekowitsch-Schmidtke R, et al. RGD-peptides for tumor targeting: biological evaluation of radioiodinated analogs and introduction of a novel glycosylated peptide with improved biokinetics. J Label Compd Radiopharm 1997; 40: 383-5.

125.Haubner R, Wester HJ, Reuning U, et al. Radiolabeled av $\beta 3$ integrin antagonists: a new class of tracers for tumor imaging. J Nucl Med 1999; 40: 1061-71.

126.Haubner R, Wester HJ, Weber WA, et al. Noninvasive imaging of av $\beta 3$ integrin expression using 18F-labeled RGD-containing glycopeptide and positron emission tomography. Cancer Res 2001; 61: 1781-5.

127.Haubner R, Wester HJ, Burkhart F, et al. Glycolated RGD-containing peptides: tracer for tumor targeting and angiogenesis imaging with improved biokinetics. J Nucl Med 2001; 42: 326-36.

128. Thumshirn G, Hersel U, Goodman SL, Kessler H. Multimeric cyclic RGD peptides as potential tools for tumor targeting: solid-phase peptide synthesis and chemoselective oxime ligation. Chem Eur J 2003; 9: 2717-25.

129.Poethko T, Schottelius M, Thumshirn G, et al. Chemoselective pre-conjugate radiohalogenation of unprotected mono- and multimeric peptides via oxime formation. Radiochim Acta 2004; 92: 317-27.

130.Poethko T, Schottelius M, Thumshirn G, et al. Two-step methodology for high yield routine radiohalogenation of peptides: 
18F-labeled RGD and octreotide analogs. J Nucl Med 2004; 45: 892-902.

131.Haubner R, Kuhnast B, Mang C, et al. 18F-glacato RGD: synthesis, radiolabeling, metabolic stability, and radiation dose estimates. Bioconj Chem 2004; 15: 61-9.

132.Haubner R, Bruchertseifer F, Bock M, Kessler H, Schwaiger M, Wester HJ. Synthesis and biological evaluation of ${ }^{99 \mathrm{~m} T \mathrm{~T}-l a b e l e d}$ cyclic RGD peptide for imaging the av $\beta 3$ expression. Nuklearmedizin 2004; 43: 26-32.

133. Alves S, Correia JDG, Gano L, et al. In vitro and in vivo evaluation of a novel $99 \mathrm{mTc}(\mathrm{CO}) 3-$ pyrazolyl conjugate of cyclo-(Arg-Gly-Asp-D-Tyr-Lys). Bioconj Chem 2007; 18: 530-7.

134.Fani M, Psimadas D, Zikos C, et al. Comparative evaluation of linear and cyclic ${ }^{99} \mathrm{mTc}$-RGD peptides for targeting of integrins in tumor angiogenesis. Anticancer Res 2006; 26: 431-4.

135.Su ZF, Liu G, Gupta S, Zhu Z, Rusckowski M, Hnatowich DJ. In vitro and in vivo evaluation of a technetium-99m-labeled cyclic RGD peptide as specific marker of $\operatorname{av} \beta 3$ integrin for tumor imaging. Bioconj Chem 2002; 13: 561-70.

136.Decristoforo C, Faintuch-Linkowski B, Rey A, et al. [99mTc]HYNIC-RGD for imaging integrin av $\beta 3$ expression. Nucl Med Biol 2006; 33: 945-52.

137. Chen X, Park R, Tohme M, Shahinian AH, Bading JR, Conti PS. MicroPET and autoradiographic imaging of breast cancer av-integrin expression using 18F- and 64Cu-labeled RGD peptide. Bioconj Chem 2004; 15: 41-9.

138. Chen X, Park R, Shahinian AH, et al. 18F-labeled RGD peptide: initial evaluation for imaging brain tumor angiogenesis. Nucl Med Biol 2004; 31: 179-89.

139. Chen X, Park R, Shahinian AH, Bading JR, Conti PS. Pharmacokinetics and tumor retention of 125I-labeled RGD peptide are improved by PEGylation. Nucl Med Biol 2004; 31: 11-9.

140.Chen X, Liu S, Hou Y, et al. MicroPET imaging of breast cancer av-integrin expression with 64Cu-labeled dimeric RGD peptides. Mol Imaging Biol 2004; 6: 350-9.

141.Chen X, Tohme M, Park R, Hou Y, Bading JR, Conti PS. MicroPET imaging of breast cancer av-integrin expression with 18F-labeled dimeric RGD peptide. Mol Imaging 2004; 3: 96-104.

142.Wu Y, Zhang X, Xiong Z, et al. MicroPET imaging of glioma integrin av $\beta 3$ expression using 64Cu-labeled tetrameric RGD peptide. J Nucl Med 2005; 46: 1707-18.

143.Zhang X, Xiong Z, Wu Y, et al. Quantitative PET imaging of tumor integrin av $\beta 3$ expression with 18F-FRGD2. J Nucl Med 2006; 47: 113-21.

144.Wu Z, Li Z, Chen $\mathrm{K}$, et al. MicroPET of tumor integrin av $\beta 3$ expression using 18F-labeled PEGylated tetrameric RGD peptide (18F-FPRGD4). J Nucl Med 2007; 48: 1536-44.

145.Li ZB, Chen K, Chen X. 68Ga-labeled multimeric RGD peptides for microPET imaging of integrin av $\beta 3$ expression. Eur J Nucl Med Mol Imaging 2008; 35: 1100-8.

146.Liu S, Cheung E, Rajopadhye M, Ziegler MC, Edwards DS. 90Yand 177Lu-labeling of a DOTA-conjugated vitronectin receptor antagonist for tumor therapy. Bioconj Chem 2001; 12: 559-68.

147.Janssen M, Oyen WJG, Massuger LFAG, et al. Comparison of a monomeric and dimeric radiolabeled RGD-peptide for tumor targeting. Cancer Biother Radiopharm 2002; 17: 641-6.

148.Janssen M, Oyen WJG, Dijkgraaf I, et al. Tumor targeting with radiolabeled av $\beta 3$ integrin binding peptides in a nude mice model. Cancer Res 2002; 62: 6146-51.

149.Janssen ML, Frielink C, Dijkgraaf I, et al. Improved tumor targeting of radiolabeled RGD-peptides using rapid dose fractionation. Cancer Biother Radiopharm 2004; 19: 399-404.

150.Liu S, Hsieh WY, Kim YS, Mohammed SI. Effect of coligands on biodistribution characteristics of ternary ligand ${ }^{99 \mathrm{~m}} \mathrm{Tc}$ complexes of a HYNIC-conjugated cyclic RGDfK dimer. Bioconj Chem 2005; $16: 1580-8$.
151.Jia B, Shi J, Yang Z, et al. ${ }^{99 m}$ Tc-labeled cyclic RGDfK dimer: initial evaluation for SPECT imaging of glioma integrin av $\beta 3$ expression. Bioconj Chem 2006; 17: 1069-76.

152.Liu S, He ZJ, Hsieh WY, Kim YS, Jiang Y. Impact of PKM linkers on biodistribution characteristics of the $99 \mathrm{mTc}$-labeled cyclic RGDfK dimer. Bioconj Chem 2006; 17: 1499-507.

153.Liu S, Hsieh WY, Jiang Y, et al. Evaluation of a ${ }^{99 m}$ Tc-labeled cyclic RGD tetramer for noninvasive imaging integrin avß3-positive breast cancer. Bioconj Chem 2007; 18: 438-46.

154.Dijkgraaf I, Liu S, Kruijtzer JAW, et al. Effect of linker variation on the in vitro and in vivo characteristics of an 111In-labeled RGD Peptide. Nucl Med Biol 2007; 34: 29-35.

155.Dijkgraaf I, Kruijtzer JAW, Liu S, et al. Improved targeting of the $\operatorname{av} \beta 3$ integrin by multimerization of RGD peptides. Eur J Nucl Med Mol Imaging 2007; 34: 267-73.

156.Liu S, Kim YS, Hsieh WY, Sreerama SG. Coligand effects on solution stability, biodistribution and metabolism of 99mTc-labeled cyclic RGDfK tetramer. Nucl Med Biol 2008; 35: 111-21.

157.Jia B, Liu Z, Shi J, et al. Linker effects on biological properties of 111In-labeled DTPA conjugates of a cyclic RGDfK dimer. Bioconj Chem 2008; 19: 201-10.

158.Wang JJ, Kim YS, He ZJ, Liu S. 99mTc-labeling of HYNIC-conjugated cyclic RGDfK dimer and tetramer using EDDA as coligand. Bioconj Chem 2008; 19: 634-42.

159.Morrison MS, Ricketts SA, Barnett J, Cuthbertson A, Tessier J, Wedge SR. Use of a novel Arg-Gly-Asp radioligand, 18F-AH111585, to determine changes in tumor vascularity after antitumor therapy. J Nucl Med 2009; 50: 116-22.

160.Kenny LM, Coombes RC, Oulie I, et al. Phase I trial of the positron-emitting Arg-Gly-Asp (RGD) peptide radioligand 18F-AH111585 in breast cancer patients. J Nucl Med 2008; 49: 879-86.

161.Beer AJ, Haubner R, Goebel $\mathrm{M}$, et al. Biodistribution and pharmacokinetics of the av $\beta 3$-selective tracer 18F-Galacto-RGD in cancer patients. J Nucl Med 2005; 46: 1333-41.

162.Haubner R, Weber WA, Beer AJ, et al. Noninvasive visualization of the activated av $\beta 3$ integrin in cancer patients by positron emission tomography and [18F]Galacto-RGD. PLOS Medicine 2005; 2: e70.

163.Beer AJ, Grosu AL, Carlsen J, et al. [18F]Galacto-RGD positron emission tomography for imaging of $\operatorname{av} \beta 3$ expression on the neovasculature in patients with squamous cell carcinoma of the head and neck. Clin Cancer Res 2007; 13: 6610-6.

164.Beer AJ, Niemeyer M, Carlsen J, et al. Patterns of av $\beta 3$ expression in primary and metastatic human breast cancer as shown by 18F-Galacto-RGD PET. J Nucl Med 2008; 49: 255-9.

165.Bach-Gansmo T, Danielsson R, Saracco A, et al. Integrin receptor imaging of breast cancer: a proof-of-concept study to evaluate $99 \mathrm{~m}$ Tc-NC100692. J Nucl Med 2006; 47: 1434-9.

166.Mammen M, Choi SK, Whitesides GM. Polyvalent interactions in biological systems: implications for design and use of multivalent ligands and Inhibitors. Angew Chem Int Ed Engl 1998; 37: 2755-94

167.Goel A, Baranowska-Kortylewicz J, Hinrichs SH, et al. 99mTc-labeled divalent and tetravalent CC49 single-chain Fv's: novel imaging agents for rapid in vivo localization of human colon carcinoma. J Nucl Med 2001; 42: 1519-27.

168.Viti F, Tarli L, Giovannoni L, Zardi L, Neri D. Increased binding affinity and valence of recombinant antibody fragments lead to improved targeting of tumoral angiogenesis. Cancer Res 1999; 59: 347-52.

169.Rajopadhye M, Harris AR, Nguyen HM, et al. RP593, a 99mTc-labeled av $\beta 3 / \operatorname{av} \beta 5$ antagonist, rapidly detects spontaneous tumors in mice and dogs. J Nucl Med 2000; 41:34P.

170.Liu S, Edwards DS, Ziegler MC, Harris AR, Hemingway SJ, Barrett JA. ${ }^{99 m T c-L a b e l i n g ~ o f ~ a ~ h y d r a z i n o n i c o t i n a m i d e ~ c o n j u-~}$ 
gated vitronectin receptor antagonist useful for imaging tumor. Bioconj Chem 2001; 12: 624-9.

171.Dijkgraaf I, Rijnders A, Soede A, et al. Synthesis of DOTA-conjugated multivalent cyclic-RGD peptide dendrimers via 1,3-dipolar cycloaddition and their biological evaluation: implications for tumor targeting and tumor imaging purposes. Org Biomol Chem 2007; 5: 935-44.

172.Boturyn D, Coll JL, Garanger E, Favrot MC, Dumy P. Template assembled cyclopeptides as multimeric system for integrin targeting and endocytosis. J Am Chem Soc 2004; 126: 5730-9.

173.Li Z, Cai W, Cao Q, et al. 64Cu-labeled tetrameric and octameric RGD peptide for small-animal PET of tumor av $\beta 3$ integrin expression. J Nucl Med 2007; 48: 1162-71.

174.Shi J, Wang L, Kim YS, et al. Improving tumor uptake and excretion kinetics of $99 \mathrm{mTc}-$ labeled cyclic Arginine-Glycine-Aspartic (RGD) dimers with triglycine linkers. J Med Chem 2008; 51: 7980-90.

175.Wang L, Kim YS, Shi J, et al. Improving tumor targeting capability and pharmacokinetics of ${ }^{99 \mathrm{~m} T c-l a b e l e d}$ cyclic RGD dimers with PEG4 linkers. Mol Pharm 2009; 6: 231-45.

176.Shi J, Wang L, Kim YS, et al. Improving tumor uptake and pharmacokinetics of $64 \mathrm{Cu}$-labeled cyclic RGD dimers with triglycine and PEG4 linkers. Bioconj Chem 2009; 20: 750-9.

177.Jia B, Shi J, Liu Z, et al. Tumor uptake of the RGD dimeric probe 99mTc-G3-2P4-RGD2 is correlated with integrin av 33 expressed on both tumor cells and neovasculature. Bioconj Chem in press.

178.Liu Z, Niu G, Shi J, et al. 68Ga-labeled cyclic RGD dimers with Gly3 and PEG4 linkers: promising agents for tumor integrin av $\beta 3$ PET imaging. Eur J Nucl Med Mol Imaging 2009; 36: 947-57.

179.Liu Z, Liu S, Wang F, Liu S, Chen X. Non-invasive imaging of tumor integrin expression using 18F-labeled RGD dimer peptide with PEG4 linkers. Eur J Nucl Med Mol Imaging 2009; 36: 1296-307.

180.Shi J, Kim YS, Chakraborty S, Jia B, Wang F, Liu S. 2-Mercaptoacetylglycylglycyl (MAG2) as a bifunctional chelator for ${ }^{99 \mathrm{mTc}}$-labeling of cyclic RGD dimers: effects of technetium chelate on tumor uptake and pharmacokinetics. Bioconj Chem 2009; 20(8): 1559-1568.

181.Shi J, Wang L, Kim YS, et al. ${ }^{99 m T c O(M A G 2-3 G 3-d i m e r): ~ a ~ n e w ~}$ integrin av $\beta 3$-targeted SPECT radiotracer with high tumor uptake and favorable pharmacokinetics. Eur J Nucl Med Mol Imaging 2009; 36: 1874-84.

182.Shi J, Kim YS, Chakraborty S, Zhou Y, Wang F, Liu S. Impact of bifunctional chelators on biological properties of 111In-labeled cyclic peptide RGD dimers. Amino Acids 2010; [Epub ahead of print].

183. Chakraborty S, Liu S, Kim YS, Shi J, Zhou Y, Wang F. Evaluation of 111In-labeled cyclic RGD peptides: tetrameric not tetravalent. Bioconj Chem 2011; Submitted.

184.Liu S. Unpublished results.

185.Davies MJ. A macro and micro view of coronary vascular insult in ischemic heart disease. Circulation 1990; 82: II38-46.

186.Farb A, Burke AP, Tang AL, et al. Coronary plaque erosion without rupture into a lipid core. A frequent cause of coronary thrombosis in sudden coronary death. Circulation 1996; 93: 1354-63.

187.Fuster V, Badimon L, Badimon JJ, Chesebro JH. The pathogenesis of coronary artery disease and the acute coronary syndromes (1). N Engl J Med 1992; 326: 242-50.

188. Myerburg RJ, Interian AJr, Mitrani RM, Kessler KM, Castellanos A. Frequency of sudden cardiac death and profiles of risk. Am J Cardiol 1997; 80: 10F-19F.

189.Moreno PR, Purushothaman KR, Fuster V, et al. Plaque neovascularization is increased in ruptured atherosclerotic lesions of human aorta: implications for plaque vulnerability. Circulation 2004; 110: 2032-8.
190.Heusch G, Kleinbongard P, Böse D, et al. Coronary microembolization: from bedside to bench and back to bedside. Circulation 2009; 120: 1822-36.

191.Schmermund A, Erbel R. Unstable coronary plaque and its relation to coronary calcium. Circulation 2001; 104: 1682-7.

192.Naghavi M, Libby P, Falk E, et al. From vulnerable plaque to vulnerable patient: a call for new definitions and risk assessment strategies: Part II. Circulation 2003; 108: 1772-8.

193.Clemetson KJ, Clemetson JM. Platelet collagen receptors. Thromb Haemost 2001; 86: 189-97.

194.Nieswandt B, Watson SP. Platelet-collagen interaction: is GPVI the central receptor? Blood 2003; 102: 449-61.

195.Scarborough RM, Kleiman NS, Phillips DR. Platelet glycoprotein IIb/IIIa antagonists. What are the relevant issues concerning their pharmacology and clinical use? Circulation 1999; 100: 437-44.

196.Ruggeri ZM. Platelets in atherothrombosis. Nat Med 2002; 8: 1227-34.

197.Fuster V, Fallon JT, Nemerson Y. Coronary thrombosis. Lancet 1996; 348 (Suppl 1): s7-10.

198.Davies MJ. Acute coronary thrombosis--the role of plaque disruption and its initiation and prevention. Eur Heart J 1995; 16 (Suppl L): 3-7.

199.Rahman S. Deep vein thrombosis prophylaxis: friend or foe. Am J Ther 2009; 16: 300-3.

200.Furie B, Furie BC. Mechanisms of thrombus formation. N Engl J Med 2008; 359: 938-49.

201.Fayad ZA, Fuster V. Clinical imaging of the high-risk or vulnerable atherosclerotic plaque. Circ Res 2001; 89: 305-16.

202.de Feyter PJ, Nieman K. New coronary imaging techniques: what to expect? Heart 2002; 87: 195-7.

203.Jaffer FA, Libby P, Weissleder R. Molecular and cellular imaging of atherosclerosis: emerging applications. J Am Coll Cardiol 2006; 47: 1328-38.

204.Wang JC, Normand SL, Mauri L, Kuntz RE. Coronary artery spatial distribution of acute myocardial infarction occlusions. Circulation 2004; 110: 278-84.

205. Choudhury RP, Fuster V, Fayad ZA. Molecular, cellular and functional imaging of atherothrombosis. Nat Rev Drug Discov 2004; 3:913-25.

206.Chan WS, Ginsberg JS. Diagnosis of deep vein thrombosis and pulmonary embolism in pregnancy. Thromb Res 2002; 107: 85-91.

207.Nissen SE, Yock P. Intravascular ultrasound: novel pathophysiological insights and current clinical applications. Circulation 2001; 103: 604-16.

208.Caussin C, Ohanessian A, Ghostine S, et al. Characterization of vulnerable nonstenotic plaque with 16-slice computed tomography compared with intravascular ultrasound. Am J Cardiol 2004; 94: 99-104.

209.Schroeder S, Kopp AF, Baumbach A, et al. Noninvasive detection and evaluation of atherosclerotic coronary plaques with multislice computed tomography. J Am Coll Cardiol 2001; 37: 1430-5.

210.Nieman K, van der Lugt A, Pattynama PM, de Feyter PJ. Noninvasive visualization of atherosclerotic plaque with electron beam and multislice spiral computed tomography. J Interv Cardiol 2003; 16: 123-8.

211.Toussaint JF, Southern JF, Fuster V, Kantor HL. T2-weighted contrast for NMR characterization of human atherosclerosis. Arterioscler Thromb Vasc Biol 1995; 15: 1533-42.

212.Kooi ME, Cappendijk VC, Cleutjens KB, et al. Accumulation of ultrasmall superparamagnetic particles of iron oxide in human atherosclerotic plaques can be detected by in vivo magnetic resonance imaging. Circulation 2003; 107: 2453-8.

213.Botnar RM, Perez AS, Witte S, et al. In vivo molecular imaging of acute and subacute thrombosis using a fibrin-binding mag- 
netic resonance imaging contrast agent. Circulation 2004; 109: 2023-9.

214.Becker W, Börner W, Borst U. 99mTc hexamethylpropyleneamineoxime (HMPAO) as a platelet label: evaluation of labelling parameters and first in vivo results. Nucl Med Commun 1988; 9: 831-42.

215.Minar E, Ehringer H, Dudczak R, et al. Indium-111-labeled platelet scintigraphy in carotid atherosclerosis. Stroke 1989; 20: 27-33.

216. Moriwaki H, Matsumoto M, Handa N, et al. Functional and anatomic evaluation of carotid atherothrombosis. A combined studies of indium-111 platelet scintigraphy and B-mode ultrasonography. Arterioscler Thromb Vasc Biol 1995; 15: 2234-40.

217.Tsimikas S, Palinski W, Halpern SE, Yeung DW, Curtiss LK, Witztum JL. Radiolabeled MDA2, an oxidation-specific, monoclonal antibody, identifies native atherosclerotic lesions in vivo. J Nucl Cardiol 1999; 6: 41-53.

218.Virgolini I, Rauscha F, Lupattelli G, et al. Autologous low-density lipoprotein labelling allows characterization of human atherosclerotic lesions in vivo as to presence of foam cells and endothelial coverage. Eur J Nucl Med 1991; 18: 948-51.

219. Virgolini I, Angelberger P, O'Grady J, Sinzinger H. Low density lipoprotein labelling characterizes experimentally induced atherosclerotic lesions in rabbits in vivo as to presence of foam cells and endothelial coverage. Eur J Nucl Med 1991; 18: 944-7.

220.Lees AM, Lees RS, Schoen FJ, et al. Imaging human atherosclerosis with $99 \mathrm{~m}$ Tc-labeled low density lipoproteins. Arteriosclerosis 1988; 8: 461-70.

221.Cerqueira MD, Stratton JR, Vracko R, Schaible TF, Ritchie JL. Noninvasive arterial thrombus imaging with ${ }^{99 \mathrm{~m} T c}$ monoclonal antifibrin antibody. Circulation 1992; 85: 298-304.

222. Greco C, Di Loreto M, Ciavolella M, et al. Immunodetection of human atherosclerotic plaque with 125I-labeled monoclonal antifibrin antibodies. Atherosclerosis 1993; 100: 133-9.

223. Matter CM, Schuler PK, Alessi P, et al. Molecular imaging of atherosclerotic plaques using a human antibody against the extra-domain B of fibronectin. Circ Res 2004; 95: 1225-33.

224.Tsimikas S, Shortal BP, Witztum JL, Palinski W. In vivo uptake of radiolabeled MDA2, an oxidation-specific monoclonal antibody, provides an accurate measure of atherosclerotic lesions rich in oxidized LDL and is highly sensitive to their regression. Arterioscler Thromb Vasc Biol 2000; 20: 689-97.

225.Tsimikas S, Palinski W, Witztum JL. Circulating autoantibodies to oxidized LDL correlate with arterial accumulation and depletion of oxidized LDL in LDL receptor-deficient mice. Arterioscler Thromb Vasc Biol 2001; 21: 95-100.

226.Iuliano L, Signore A, Vallabajosula S, et al. Preparation and biodistribution of 99mtechnetium labelled oxidized LDL in man. Atherosclerosis 1996; 126: 131-41.

227.Shaw PX, Hörkkö S, Tsimikas S, et al. Human-derived anti-oxidized LDL autoantibody blocks uptake of oxidized LDL by macrophages and localizes to atherosclerotic lesions in vivo. Arterioscler Thromb Vasc Biol 2001; 21: 1333-9.

228. Ginsberg HN, Goldsmith SJ, Vallabhajosula S. Noninvasive imaging of technetium-99m-labeled low density lipoprotein uptake by tendon xanthomas in hypercholesterolemic patients. Arteriosclerosis 1990; 10: 256-62.

229.Mettinger KL, Larsson S, Ericson K, Casseborn S. Detection of atherosclerotic plaques in carotid arteries by the use of 123I-fibrinogen. Lancet 1978; 1: 242-4.

230. Barker PL, Bullens S, Bunting S, et al. Cyclic RGD peptide analogues as antiplatelet antithrombotics. J Med Chem 1992; 35: 2040-8.

231.Lu P, Zanzonico P, Lister-James J, et al. Biodistribution and autoradiographic localization of I-125-labeled synthetic peptide in aortic atherosclerosis in cholesterol-fed rabbits. Am J Ther 1996; 3: 673-80.
232.Hardoff R, Braegelmann F, Zanzonico P, et al. External imaging of atherosclerosis in rabbits using an 123I-labeled synthetic peptide fragment. J Clin Pharmacol 1993; 33: 1039-47.

233. Muto P, Lastoria S, Varrella P, et al. Detecting deep venous thrombosis with technetium-99m-labeled synthetic peptide P280. J Nucl Med 1995; 36: 1384-91.

234.Lister-James J, Knight LC, Maurer AH, Bush LR, Moyer BR, Dean RT. Thrombus imaging with a technetium-99m-labeled activated platelet receptor-binding peptide. J Nucl Med 1996; 37: 775-81.

235.Bates SM, Lister-James J, Julian JA, Taillefer R, Moyer BR, Ginsberg JS. Imaging characteristics of a novel technetium Tc-99m-labeled platelet glycoprotein $\mathrm{IIb} / \mathrm{III}$ receptor antagonist in patients with acute deep vein thrombosis or a history of deep vein thrombosis. Arch Intern Med 2003; 163: 452-6.

236.Taillefer R, Thérasse E, Turpin S, Lambert R, Robillard P, Soulez G. Comparison of early and delayed scintigraphy with 99mTc-apcitide and correlation with contrast-enhanced venography in detection of acute deep vein thrombosis. J Nucl Med 1999; 40: 2029-35.

237.Carretta RF, Streek PV, Weiland FL. Optimizing images of acute deep-vein thrombosis using technetium-99m-apcitide. J Nucl Med Technol 1999; 27: 271-5.

238.Taillefer R, Edell S, Innes G, Lister-James J. Acute thromboscin-

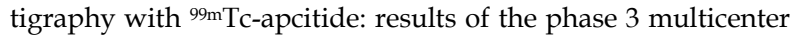
clinical trial comparing ${ }^{99 m}$ Tc-apcitide scintigraphy with contrast venography for imaging acute DVT. Multicenter Trial Investigators. J Nucl Med 2000; 41: 1214-23.

239.Dunzinger A, Hafner F, Schaffler G, Piswanger-Soelkner JC, Brodmann M, Lipp RW. ${ }^{99 \mathrm{~m} T c-a p c i t i d e ~ s c i n t i g r a p h y ~ i n ~ p a t i e n t s ~}$ with clinically suspected deep venous thrombosis and pulmonary embolism. Eur J Nucl Med Mol Imaging 2008; 35: 2082-7.

240.Mousa SA, Bozarth JM, Edwards S, Carroll T, Barrett J. Novel technetium-99m-labeled platelet GPIIb/IIIa receptor antagonists as potential imaging agents for venous and arterial thrombosis. Coron Artery Dis 1998; 9: 131-41.

241.Liu S, Edwards DS, Looby RJ, et al. Labeling a hydrazino nicotinamide-modified cyclic IIb/IIIa receptor antagonist with ${ }^{99 \mathrm{mTC}}$ using aminocarboxylates as coligands. Bioconj Chem 1996; 7: 63-71.

242.Liu S, Edwards DS, Looby RJ, et al. Labeling cyclic glycoprotein $\mathrm{IIb} / \mathrm{III}$ receptor antagonists with ${ }^{99 \mathrm{~m} T \mathrm{C}}$ by the preformed chelate approach: effects of chelators on properties of [99mTc]chelator-peptide conjugates. Bioconj Chem 1996; 7: 196-202.

243.Harris TD, Rajopadhye M, Damphousse PR, et al. Tc-99m-labeled fibrinogen receptor antagonists: design and synthesis of cyclic RGD peptides for the detection of thrombi. Bioorg Med Chem Lett 1996; 6: 1741-6.

244.Barrett JA, Damphousse DJ, Heminway SJ, et al. Biological evaluation of $99 \mathrm{~m} \mathrm{Tc}$-labeled cyclic glycoprotein IIb/IIIa receptor antagonists in the canine arteriovenous shunt and deep vein thrombosis models: effects of chelators on biological properties of [ ${ }^{99 \mathrm{mTc}} \mathrm{Tch}$ chator-peptide conjugates. Bioconj Chem 1996; 7: 203-8.

245.Edwards DS, Liu S, Barrett JA, et al. New and versatile ternary ligand system for technetium radiopharmaceuticals: water soluble phosphines and tricine as coligands in labeling a hydrazinonicotinamide-modified cyclic glycoprotein IIb/IIIa receptor antagonist with 99mTc. Bioconj Chem 1997; 8: 146-54.

246.Barrett JA, Crocker AC, Damphousse DJ, et al. Biological evaluation of thrombus imaging agents utilizing water soluble phosphines and tricine as coligands when used to label a hydrazinonicotinamide-modified cyclic glycoprotein IIb/IIIa receptor antagonist with 99mTc. Bioconj Chem 1997; 8: 155-60.

247.Liu S, Edwards DS, Harris AR. A novel ternary ligand system for ${ }^{99} \mathrm{mTc}$-labeling of hydrazino nicotinamide-modified biologi- 
cally active molecules using imine-N-containing heterocycles as coligands. Bioconj Chem 1998; 9: 583-95.

248.Edwards DS, Liu S, Harris AR, Poirier MJ, Ewels BA. 99mTc-labeling of hydrazones of a hydrazinonicotinamide conjugated cyclic peptide. Bioconj Chem 1999; 10: 803-7.

249. Oyen WJ, Boerman OC, Brouwers FM, et al. Scintigraphic detection of acute experimental endocarditis with the technetium-99m labelled glycoprotein $\mathrm{IIb} / \mathrm{III}$ a receptor antagonist DMP444. Eur J Nucl Med 2000; 27: 292-9.

250.Mitchel J, Waters D, Lai T, et al. Identification of coronary thrombus with a IIb/IIIa platelet inhibitor radiopharmaceutical, technetium-99m DMP-444: A canine model. Circulation 2000; 101: 1643-6.

251.Brouwers FM, Oyen WJ, Boerman OC, et al. Evaluation of Tc-99m-labeled glycoprotein $\mathrm{IIb} / \mathrm{III}$ a receptor antagonist DMP444 SPECT in patients with infective endocarditis. Clin Nucl Med 2003; 28: 480-4.

252.Scharn DM, Oyen WJ, Klemm PL, Wijnen MH, vanderVliet JA. Assessment of prosthetic vascular graft thrombogenicity using the technetium-99m labeled glycoprotein IIb/IIIa receptor antagonist DMP444 in a dog model. Cardiovasc Surg 2002; 10 : 566-9.

253.Klem JA, Schaffer JV, Crane PD, et al. Detection of deep venous thrombosis by DMP444, a platelet IIb/IIIa antagonist: a preliminary report. J Nucl Cardiol 2000; 7: 359-64.

254.Sakuma T, Sari I, Goodman CN, Lindner JR, Klibanov AL, Kaul $\mathrm{S}$. Simultaneous integrin av $\beta 3$ and glycoprotein IIb/IIIa inhibition causes reduction in infarct size in a model of acute coronary thrombosis and primary angioplasty. Cardiovasc Res 2005; 66: 552-61.

255.Sakuma T, Sklenar J, Leong-Poi H, Goodman NC, Glover DK, Kaul S. Molecular imaging identifies regions with microthromboemboli during primary angioplasty in acute coronary thrombosis. J Nucl Med 2004; 45: 1194-200.

256.Aruva MR, Daviau J, Sharma SS, Thakur ML. Imaging thromboembolism with fibrin-avid 99mTc-peptide: evaluation in swine. J Nucl Med 2006; 47: 155-62.

257.Knight LC. Radiopharmaceuticals for thrombus detection. Semin Nucl Med 1990; 20: 52-67.

258. Cerqueira MD. Current status of radionuclide tracer imaging of thrombi and atheroma. Semin Nucl Med 1999; 29: 339-51.

259.Taillefer R. Radiolabeled peptides in the detection of deep venous thrombosis. Semin Nucl Med 2001; 31: 102-23.

260.Bernarducci MP. Radiolabeled peptides: overcoming the challenges of post-surgical patient management of venous thromboembolism. Surg Technol Int 2004; 12: 50-67.

261.Dobrucki LW, Sinusas AJ. PET and SPECT in cardiovascular molecular imaging. Nat Rev Cardiol 2010; 7: 38-47.

262.Schillaci O, Danieli R, Padovano F, Testa A, Simonetti G. Molecular imaging of atherosclerotic plaque with nuclear medicine techniques. Int J Mol Med 2008; 22: 3-7.

263.Langer HF, Haubner R, Pichler BJ, Gawaz M. Radionuclide imaging: a molecular key to the atherosclerotic plaque. J Am Coll Cardiol 2008; 52: 1-12.

264.Davies JR, Rudd JH, Weissberg PL. Molecular and metabolic imaging of atherosclerosis. J Nucl Med 2004; 45: 1898-907.

265.Langer H, Schönberger T, Bigalke B, Gawaz M. Where is the trace? Molecular imaging of vulnerable atherosclerotic plaques. Semin Thromb Hemost 2007; 33: 151-8.

266.Liu S, Edwards DS, Harris AR, et al. Towards developing a non-SnCl2 formulation for RP444, a new radiopharmaceutical for thrombus imaging. J Pharm Sci 2001; 90: 114-23.

267.Cai W, Rao J, Gambhir SS, Chen X. How molecular imaging is speeding up antiangiogenic drug development. Mol Cancer Ther 2006; 5: 2624-33.
268.Niu G, Chen X. Has molecular and cellular imaging enhanced drug discovery and drug development? Drugs R D 2008; 9: 351-68.

269. Creamer D, Allen M, Sousa A, Poston R, Barker J. Altered vascular endothelium integrin expression in psoriasis. Am J Pathol 1995; 147: 1661-7.

270.Waldeck J, Häger F, Höltke C, et al. Fluorescent reflectance imaging of macrophage-rich atherosclerostic plaques using avß3 integrin-targeted fluorochrome. J Nucl Med 2008; 49: 1845-51.

271.Meoli DF, Sadeghi MM, Krassilnikova S, et al. Noninvasive imaging of myocardial angiogenesis following experimental myocardial infarction. J Clin Invest 2004; 113: 1684-91.

272.Pichler BJ, Kneilling M, Haubner R, et al. Imaging of delayed-type hypersensitivity reaction by PET and 18F-Galacto-RGD. J Nucl Med 2005; 46: 184-9. 